\title{
Verification of Hourly \\ Forecasts of Wind Turbine \\ Power Output
}

H. L. Wegley

August 1984

Prepared for the U.S. Department of Energy under Contract DE-AC06-76RLO 1830

Pacific Northwest Laboratory Operated for the U.S. Department of Energy by Battelle Memorial Institute 


\title{
DISCLAIMER
}

This report was prepared as an account of work sponsored by an agency of the United States Government. Neither the United States Government nor any agency thereof, nor any of their employees, makes any warranty, express or implied, or assumes any legal liability or responsibility for the accuracy, completeness, or usefulness of any information, apparitus, product, or process disclosed, or represents that its use would not infringe privately owned rights. Reference herein to any specific commercial product, process, or service by trade name, trademark, manufacturer, or otherwise, does not necessarily constitute or imply its endorsement, recommendation, or favoring by the United States Government or any agency thereof. The views and opinions of authors expressed herein do not necessarily state or reflect those of the United States Government or any agency thereof.

\author{
PACIFIC NORTHWEST LABOR,ATORY \\ operated by \\ BATTELLE \\ for the \\ UNITED STATES DEPARTMENT O= ENERGY \\ under Contract DE-AC06-76RLO 1830
}

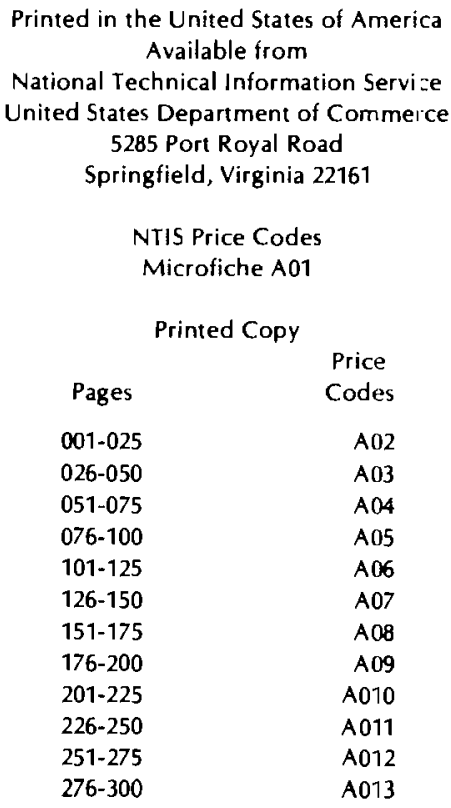


VERIFICATION OF HOURLY FORECASTS

OF WIND TURBINE POWER OUTPUT

H. L. Wegley

August 1984

Prepared for

the U.S. Department of Energy

under Contract DE-AC06-76RLO-1830

Pacific Northwest Laboratory Richland, Washington 99352 


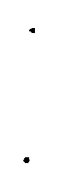

. 


\section{ACKNOWLEDGMENTS}

The author wishes to thank Bill Formica and Mike Kosorok for their help in software development for data analysis, Scott Heflick for reviewing the draft report and Debbie Atkin for typing the manuscript. 

A verification of hourly average wind speed forecasts in terms of hourly average power output of a MOD-2 was performed for four sites. Site-specific probabilistic transformation models were developed to transform the forecast and observed hourly average speeds to the percent probability of exceedance of an hourly average power output. (This transformation model also appears to have value in predicting annual energy production for use in wind energy feasibility studies.)

The transformed forecasts were verified in a deterministic sense (i.e., as continuous values) and in a probabilistic sense (based upon the probability of power output falling in a specified category). Since the smoothing effects of time averaging are very pronounced, the $90 \%$ probability of exceedance was built into the transformation models.

Semiobjective and objective (model output statistics) forecasts were made compared for the four sites. The verification results indicate that the correct category can be forecast an average of $75 \%$ of the time over a 24 -hour period. Accuracy generally decreases with projection time out to $\sim 18$ hours and then may increase due to the fairly regular diurnal wind patterns that occur at many sites. The ability to forecast the correct power output category increases with increasing power output because occurrences of high hourly average power output (near rated) are relatively rare and are generally not forecast. The semiobjective forecasts proved superior to model output statistics in forecasting high values of power output and in the shorter time frames ( 1 to 6 hours). However, model output statistics were slightly more accurate at other power output levels and times.

Noticeable differences were observed between deterministic and probabilistic (categorical) forecast verification results. This serves as a warning that forecasts should be verified in the format and context required by the end user in order to determine their real value. 


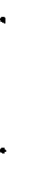




\section{CONTENTS}

ACKNOWLEDGMENTS

SUMMARY

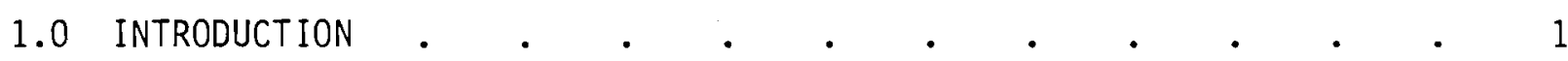

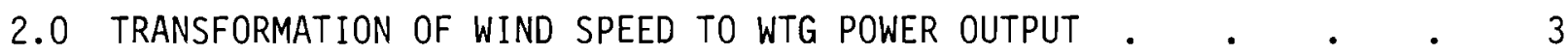

2.1 TRANSFORMATION UNCERTAINTIES . . . . . . . . . 3

2.1.1 Dependency Upon WTG Operating Characteristics . . 3

2.1.2 Smoothing Effects of Time Averaging . . . . . 4

2.1.3 Site-to-Site Variability in Wind

Characteristics . $. \quad . \quad . \quad . \quad . \quad . \quad .66$

2.2 APPLICABILITY OF THE TRANSFORMATION MODEL $\quad . \quad . \quad . \quad . \quad 8$

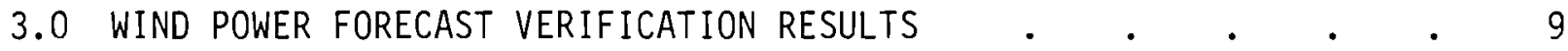

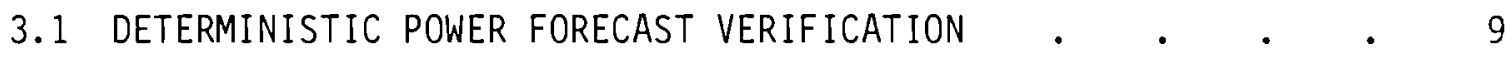

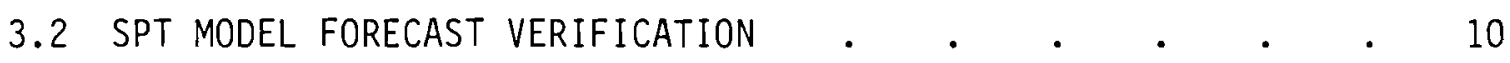

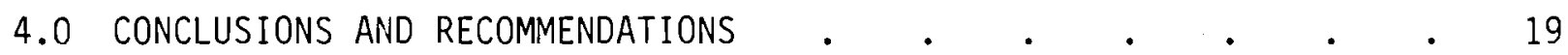

5.0 REFERENCES $\quad . \quad \ldots \quad$.

APPENDIX A - LISTING OF SPT MODEL MOD-2 POWER OUTPUT FORECAST VERIFICATION RESULTS $. \quad \cdot \quad \cdot \quad . \quad \cdot \quad \cdot \quad \cdot \quad \cdot A-1$ 


\section{FIGURES}

2.1 Site Specific SPT Models Used for Speed-to-Power Conversions

3.1 Sites for Which Semiobjective and MOS Wind Forecasts were Compared.

3.2 Computation of the Heidke Skill Score . . . . . . 12

\section{$\underline{\text { TABLES }}$}

2.1 Example Joint Histogram for Hourly Average Wind Speed and Wind

Power Output for a MOD-2 .

3.1 Deterministic Verification of SO and MOS Power Output

Forecasts . . . . . • • . . . . , 11

3.2 Site-to-Site Comparison of MOS and SO Hourly MOD-2 Power

Forecasts - All Forecast Times and Power Categories

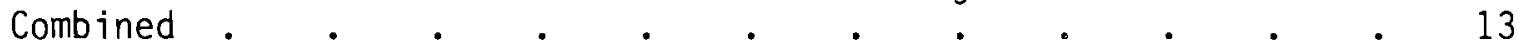

3.3 Comparison of Hourly MOD-2 Wind Power Forecast Reliability and Skill as a Function of Projection Time . . . . . 15

3.4 Comparison of Hourly MOD-2 Wind Power Forecast Reliability as a Function of Power Output Category . . . . . . 16

A.1 90\% Confidence SPT Model Hourly Average Speed Values for Block Island, RI . . . . . . . . . . . A-1

A.2 Semiobjective SPT Wind Power Forecast Verification for Block Island, RI

A.3 MOS SPT Wind Power Forecast Verification for Block Island, RI . . . . . . . . . . A-3

A.4 90\% Confidence SPT Model Hourly Average Speec Values for Finley, ND

A.5 Semiobjective SPT Wind Power Forecast Verification for Finley, ND

A.6 90\% Confidence SPT Model Hourly Average Speec Values for Huron, SD .

A.7 MOS SPT Wind Power Forecast Verification for Huron, SD . . . A-7 
$\underline{\text { TABLES (Continued) }}$

A.8 90\% Confidence SPT Model Hourly Average Speed Values for San Gorgonio, CA . . . . . . . . . . . A-8

A.9 Semiobjective SPT Wind Power Forecast Verification for San Gorgonio, CA . . . . . . . . . . A-9

A.10 MOS SPT Wind Power Forecast Verification for San Gorgonio, CA . . . . . . . . . . A-10 

VERIFICATION OF HOURLY FORECASTS OF WIND TURBINE POWER OUTPUT

Harry L. Wegley

\subsection{INTRODUCTION}

Previous studies(a) have indicated that significant penetrations of wind turbine generators (WTGs) into a utility power system will affect both the utility operations planning (daily unit scheduling and commitment) and the real-time operations (control of generating units in the minutes to a few hours time frames). The ability to accurately predict WTG power output may become a requirement for some utilities.

Early work in estimating the predictability of the wind dealt with the predictability of hourly average wind speeds for utility operations planning. This work included studies by the International Energy Agency (Bodin and Fredriksson 1981) and studies within the United States Federal Wind Energy Program (Gilhousen [1980], Wegley [1982], and Wegley and Formica [1983]).

Since the completion of these earlier studies, large WTG performance data have been collected and useful models of large WTG energy production have been developed (Miller and Formica [1984], Pennell and Miller [1982]). Consequently, it is now possible to make some quantitative statements about the accuracy of large WTG power output forecasts. Furthermore, limited investigation into the use and value of wind forecasting in day-to-day utility operations planning has indicated that sufficiently reliable wind power forecasts could have significant value to an electric utility (Goldenblatt, Wegley and Miller 1983).

This report is a brief, and by no means exhaustive, summary analysis of hourly average wind speed forecasts that have been verified in terms of the expected power output of a single large WTG. Section 2 of the report presents

(a) Schlueter, Park and Bouwmeester (1983), Lee and Yamayee (1981), Reddoch et al. (1981). 
the development of a model for transformation of hourly average wind speed forecasts to WTG hourly power output. Section 3 fresents a comparison of WTG power forecast accuracy (using the transformation model) for two types of wind forecasting techniques: semiobjective and totally objective. In Section 4 conclusions and recommendations are made based upen the results of the forecast comparisons made and the static transformation moclel used. 


\subsection{TRANSFORMATION OF WIND SPEED TO WTG POWER OUTPUT}

The verification of forecast hourly average wind speeds in terms of hourly average WTG power output requires a transformation of wind speed to equivalent power output. Two types of uncertainty will be associated with the verification of any such transformed forecasts:

- uncertainty introduced in the transformation of hourly averaged speed to hourly averaged power output

- uncertainty in the ability of a forecast technique (or forecaster) to predict a categorically correct hourly average wind speed.

The remainder of this section discusses the manner in which the first of these two areas of uncertainty was dealt with in this study. (Section 3.2 explains how uncertainties in the forecast were taken into account during forecast verification.)

\subsection{TRANSFORMATION UNCERTAINTIES}

When developing a transformation model, factors contributing to the variability of WTG power output with time-averaged wind speeds are:

- dependency upon the specific WTG operating characteristics

- smoothing effects of time averaging

- site-to-site variability in wind characteristics (i.e., the frequency and magnitude of wind speed fluctuations that interact with the WTG operating strategy)

- interannual variations in site wind characteristics (i.e., representativeness of the wind data used).

\subsubsection{Dependency Upon WTG Operating Characteristics}

Because most large WTGs are controlled by one or more microprocessors, the WTG can be modelled logically as a weakly connected, deterministic, finitestate machine. Such a model requires a memory of state transitions to determine 
the current state of the machine; therefore, it must include the set of all possible state transitions. Hourly averaging of wind speed data prevents the maintaining of such a memory.

Hourly time averaging of wind speeds masks the minute-to-minute variations in speed that interact with the operating strategy of a large wind turbine. Since the operating strategy varies from machine to machine, it is not possible to provide a completely hardware-independent model of the relationship between hourly averaged wind speeds and WTG hourly power froduction. Consequently, a single large wind turbine, the MOD-2, was selectec for analysis. The operating strategy of this machine has been accurately modeled (Mi1ler and Formica 1984). By limiting the study to the MOD-2, the uncertainty in the transformation of wind speed to power output was greatly reduced and the power output could be modeled using available software.

\subsubsection{Smoothing Effects of Time Averaging}

Even for a single WTG operating strategy, the: smoothing effects of hourly averaging of the wind speed still introduce uncertainty into the speed-topower-output transformation. However, specifying the WTG and operating strategy permits a simpler model of the speed-to-power transformation. Furthermore, if a static $^{(a)}$ probabilistic transformation (SPT) model is used, then the level of confidence in the transformation can be specified. Primarily for this reason an SPT model of MOD-2 power output was developed as described below.

First, a time series of 2-minute instantaneous observations of wind speed and direction was used to drive a quasi-dynamic ("inite-state machine) model of the MOD-2 (Miller and Formica 1984). Second, the input wind speeds were averaged over a 1-hour interval and compared to the hourly averaged 2-minute quasi-dynamic model power output information. These data were placed in a histogram to show the joint distribution of hourly average wind speed and equivalent MOD-2 power output (see Table 2.1).

As Table 2.1 indicates, there is a distribution of power output levels for any given hourly average wind speed. To establish an SPT model of power

Static simply means that dynamic relationships between wind speed and WTG power output are not directly accounted for. 
TABLE 2.1. Example Joint Histogram for Hourly Average Wind Speed and Wind Power Output for a MOD-2

$$
\text { Hourly Average Wind Speed }(\mathrm{m} / \mathrm{s})(\mathrm{a})
$$

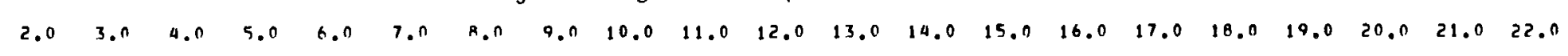

\begin{tabular}{|c|c|c|c|c|c|c|c|c|c|c|c|c|c|c|c|c|c|c|c|c|c|c|}
\hline & & 2.0 & $3 . n$ & 4.0 & 5.0 & 6.0 & $7 . n$ & $R . n$ & 9.0 & 10.0 & 11.0 & 12.0 & 13.0 & 14.0 & 15.0 & 16.0 & 17.0 & 18.0 & 19.0 & 20.0 & 21.0 & 22.0 \\
\hline & $25 \mathrm{nn}$. & 0 & 0 & n & $n$ & 0 & $n$ & n & n & 0 & 0 & 0 & 22 & 208 & 317 & 321 & 248 & 117 & 65 & G & 0 & 0 \\
\hline & 2375. & 0 & 0 & $n$ & 0 & 0 & 0 & $n$ & 0 & n & 0 & 0 & 104 & 120 & 44 & A & 0 & 1 & 1 & 0 & 0 & 0 \\
\hline & 2250. & 0 & 0 & $n$ & $n$ & $r$ & $n$ & $n$ & $n$ & $n$ & 0 & 5 & 160 & $\Delta 2$ & 12 & 1 & 2 & 5 & ? & 0 & 0 & 0 \\
\hline 8 & 2125 & 0 & 0 & $n$ & 0 & 0 & $n$ & $n$ & $n$ & $r$ & 0 & 80 & 86 & 10 & 3 & 2 & 2 & 4 & $n$ & 0 & 0 & 0 \\
\hline 3 & 2000. & 0 & 0 & 0 & 0 & 0 & $n$ & 0 & $n$ & $n$ & 0 & 102 & 19 & 7 & A & 2 & 3 & 6 & b & 1 & n & o \\
\hline $\bar{z}$ & 1875. & $n$ & n & 0 & 0 & 0 & $n$ & $n$ & 0 & 0 & 2 & 132 & 15 & 10 & 3 & 0 & 0 & " & 1 & 0 & 0 & 0 \\
\hline 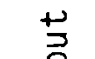 & 1750. & $c$ & $n$ & $n$ & 0 & 0 & 0 & $n$ & $n$ & 0. & A5 & $\Delta A$ & 12 & $a$ & 1 & 0 & 6 & 1 & 7 & 1 & 0 & 0 \\
\hline$\stackrel{8}{+}$ & $1+25$. & 0 & $n$ & $n$ & 0 & $n$ & $n$ & 0 & 0 & 0 & 140 & 18 & 3 & 6 & 1 & 1 & 0 & 1 & 2 & 0 & 0 & 0 \\
\hline & 1500. & 0 & 0 & $n$ & 0 & 0 & $n$ & $n$ & $n$ & $n$ & 152 & 16 & 5 & 1 & 0 & 1 & 4 & 3 & 9 & 1 & 0 & 0 \\
\hline$\frac{1}{3}$ & 1375. & $n$ & 0 & $n$ & 0 & 0 & 0 & 0 & 0 & An & 65 & 9 & 3 & 2 & 0 & 0 & 1 & 4 & 2 & 1 & 0 & \\
\hline ठ์ & 1250. & 0 & $n$ & $n$ & 0 & 0 & $n$ & $n$ & $n$ & 121 & 31 & A & 6 & 0 & $n$ & 0 & 0 & 6 & 3 & 0 & $n$ & 0 \\
\hline 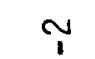 & 1125. & 0 & $n$ & $n$ & 0 & 0 & 0 & 0 & 1 & 136 & $\ldots 24$ & 5 & 2 & 2 & 0 & 0 & 1 & 2 & 1 & a & 0 & n \\
\hline 율 & 1000. & 0 & $n$ & $n$ & 0 & 0 & $n$ & $n$ & 90 & 54 & 15 & 5 & 2 & $n$ & $n$ & 0 & 3 & 1 & 5 & 4 & 0 & 0 \\
\hline 2 & P 75 . & $n$ & $n$ & 0 & $n$ & 0 & $n$ & 0 & 107 & at & 19 & 4 & 1 & 1 & 0 & $n$ & 1 & 0 & 1 & 0 & 0 & n \\
\hline 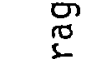 & 750. & 0 & $n$ & $n$ & 0 & $n$ & 0 & 3 & 136 & 21 & 10 & 2 & 1 & 1 & ? & $n$ & a & 2 & 7 & 3 & 0 & 0 \\
\hline & 625. & 0 & 0 & $n$ & 0 & $n$ & 1 & 43 & 73 & 21 & e & 1 & 0 & $n$ & c & $n$ & 0 & 2 & 2 & 2 & 0 & 0 \\
\hline & 500. & 0 & 0 & $n$ & 0 & $n$ & 5 & 124 & 47 & 15 & 5 & 1 & 0 & $n$ & 0 & 0 & 0 & 1 & 3 & h & n & 0 \\
\hline 2 & 375. & 0 & 0 & $n$ & 1 & 1 & 19 & 139 & 20 & 15 & 3 & $?$ & $n$ & 0 & 0 & 0 & 0 & 0 & 5 & 2 & 0 & \\
\hline 궁 & 250. & 0 & 0 & 0 & 1 & 0 & GR & 115 & 45 & 5 & 3 & 1 & 0 & 0 & $n$ & 0 & 1 & 0 & 3 & 6 & 2 & \\
\hline & 125. & 0 & 0 & 0 & A & 27 & 105 & 94 & 31 & 5 & 3 & 0 & 0 & 1 & 0 & 0 & 0 & 0 & 2 & a & 1 & \\
\hline & $n$. & 69 & 219 & 414 & 644 & 775 & 3PA & A9 & $2 \mathrm{~B}$ & 5 & 1 & $n$ & 1 & 0 & 0 & 0 & 0 & 1 & 5 & 51 & 14 & \\
\hline
\end{tabular}


output as a function of wind speed, a probability level of $90 \%$ (on the power output) was selected and a polynomial fit to the data was constructed such that the threshold wind speed for any given power output level marks the minimum hourly average power output level one would expect to achieve $90 \%$ of the time that the hourly average wind speed threshold is met or exceeded.

Selection of $90 \%$ as the confidence level to te used was somewhat subjective. The rationale behind the selection was that this level was not so high that no useful information would be provided at the conficence level and yet it was not so low that using it to transform average speed to power output would result in low confidence in any wind forecasting verificction statistics generated.

\subsubsection{Site-To-Site Variability in Wind Characteristics}

Verification of the wind speed forecasts that have been generated for several DOE candidate WTG sites (Wegley and Formica 1983) required examination of site-to-site variability of the SPT model. For this analysis, four sites of interest were examined:

1. San Gorgonio Pass, California

2. Block Island, Rhode Island

3. Huron, South Dakota

4. Finley, North Dakota.

Furthermore, the steady-state performance curve for the MOD-2 was broken into three wind speed areas $(\mathrm{a})$ :

- cut-in to near rated

- near rated to near high-speed cutout

- near to above high-speed cutout.

It was found that the effects of hourly averaging varied sufficiently between the four sites and the three wind speed regions aiong the MOD-2 performance curve that site-specific models were warranted. The four site-specific models are depicted in Figure 2.1. It is interesting to note that for each site, there were two distinct inflection points in the cut-in to rated range; as a result, a third-order polynomial was used to fit shis region. In addition,

(a) For the MOD-2 the cut-in, rated and cutout speeds used were $6.26 \mathrm{~m} / \mathrm{s}$ (14 $\mathrm{mph}), 12.26 \mathrm{~m} / \mathrm{s}(27 \mathrm{mph})$ and $18.78 \mathrm{~m} / \mathrm{s}$ (4: $\mathrm{mph})$, respectively. 


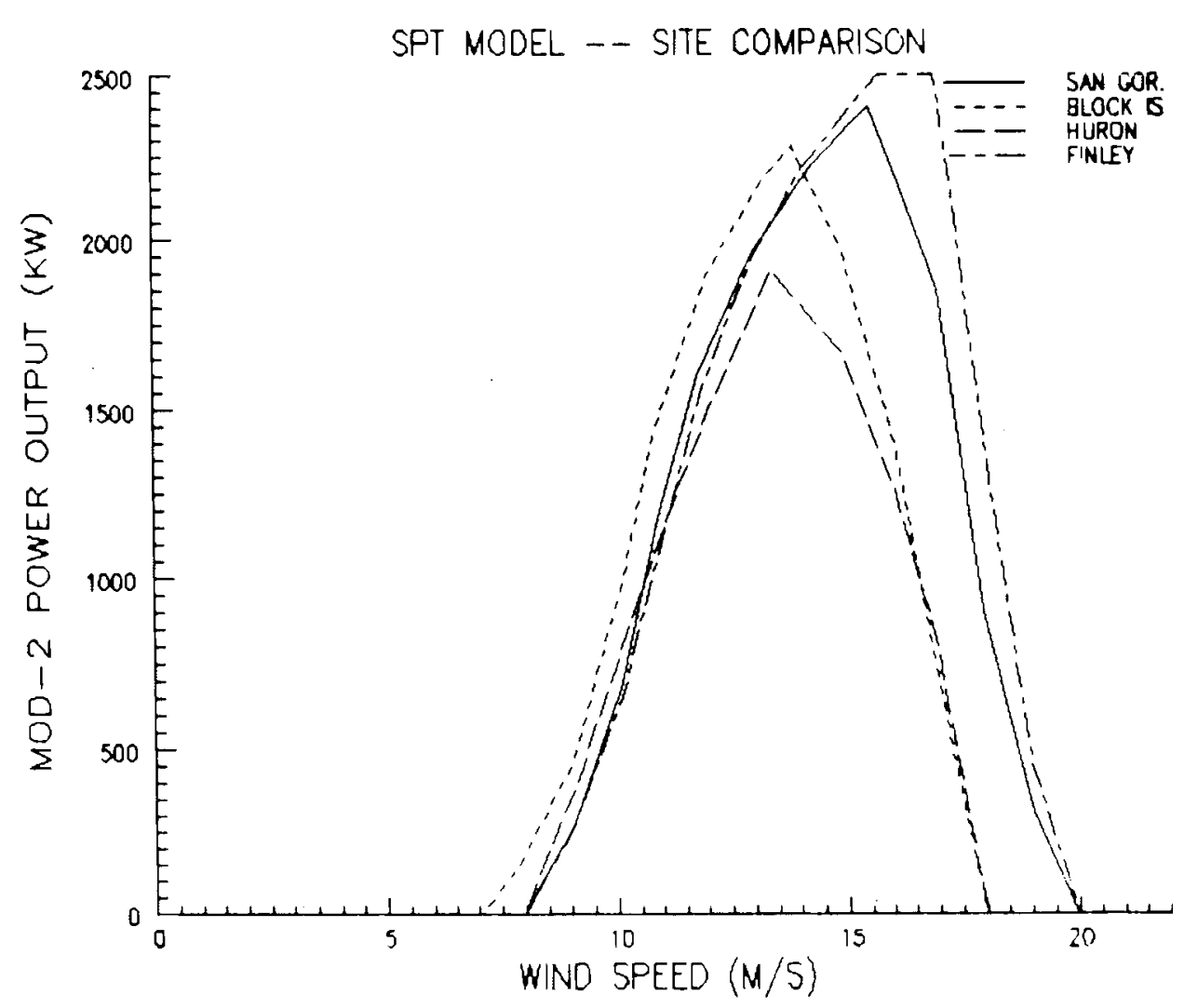

FIGURE 2.1. Site-Specific SPT Models Used for Speed-to-Power Conversions

the wind characteristics at three of the four sites were such that at no speed could rated power be inferred from hourly averaged wind speed with $90 \%$ confidence. Finally, in the cutout region of speeds, the "tail off" of power was very dependent upon the site wind characteristics. (It varied by as much as $2000 \mathrm{~kW}$ between Block Island and Finley at $\sim 18 \mathrm{~m} / \mathrm{s}$.)

Further examination of static models is beyond the scope of this project; however it does appear that better regression models could be developed to predict performance of large WTGs based upon some knowledge of the wind speed frequency distribution and of the spectral characteristics of wind speeds at a site (primarily fluctuations on the order of a few minutes, i.e., those that would interact with the WTG operating strategy).

Since the MOD-2 simulated wind power data used in this study were limited to 1 year, it was not possible to examine interannual variations in the speedto-power transformation model. 


\subsection{APPLICABILITY OF THE TRANSFORMATION MODEL}

Under the constraints imposed by the averagirg of the input wind data the SPT model provides a fairly simple but reliable model of the probability of attaining an average power output level over the time-averaging interval. As previously mentioned, this model could possibly be improved by using methods such as stepwise screening regression to build a linear regression model that uses other predictors (such as turbulence spectra of a site).

One primary weakness of the analysis done in this study is that it only examines probabilities of exceedance. It would hive also been useful to examine the forecasts from the point of view of the probability that the average power remains below various threshold levels (i.e., cut-in, rated power, high-speed cutout, etc.). However, the key issue underlying this forecast verification scheme is how well the forecasts discriminate between instances where the wind remains on one side of a given threshold. The same discriminative ability is required for predicting nonexceedance thresholds; consequently, some inferences can be drawn regarding forecasting skill in any situation where the ability to discriminate between threshold values of hourly averaged wind speed is an issue.

When interpreting the verification results presented in Section 3 , it should be remembered that the forecasts are for single sites and single wind turbines. One would certainly expect that smoothing of the microscale phenomena that affect power output from one WTG would reduce the variability of power output over a mesoscale cluster of WTGs and that some mesoscale effects might be smoothed by including multiple clusters of wind turbines (spread over synoptic-scale areas of a few hundred miles). As a result, the wind power forecasting accuracy results presented in this report should be interpreted as a lower bound on hourly wind power forecasting accuracy. 


\subsection{WIND POWER FORECAST VERIFICATION RESULTS}

Semiobjective (SO) and objective (model output statistics or MOS) forecasts of hourly average wind speed were compared by Wegley and Formica (1983). When these two types of forecasts were verified in terms of their respective abilities to forecast MOD-2 hourly average power output, the results obtained were somewhat different from, though not inconsistent with, the previous wind speed verification by Wegley and Formica. When viewing the verification results presented in this section one must remember that the SO forecasts were produced during a period of forecaster learning while the MOS forecasts represent a more mature forecasting technique.

The period of forecast comparison is March and April (1979 for the MOS and 1982 for the SO forecasts); the sites compared are shown in Figure 3.1.

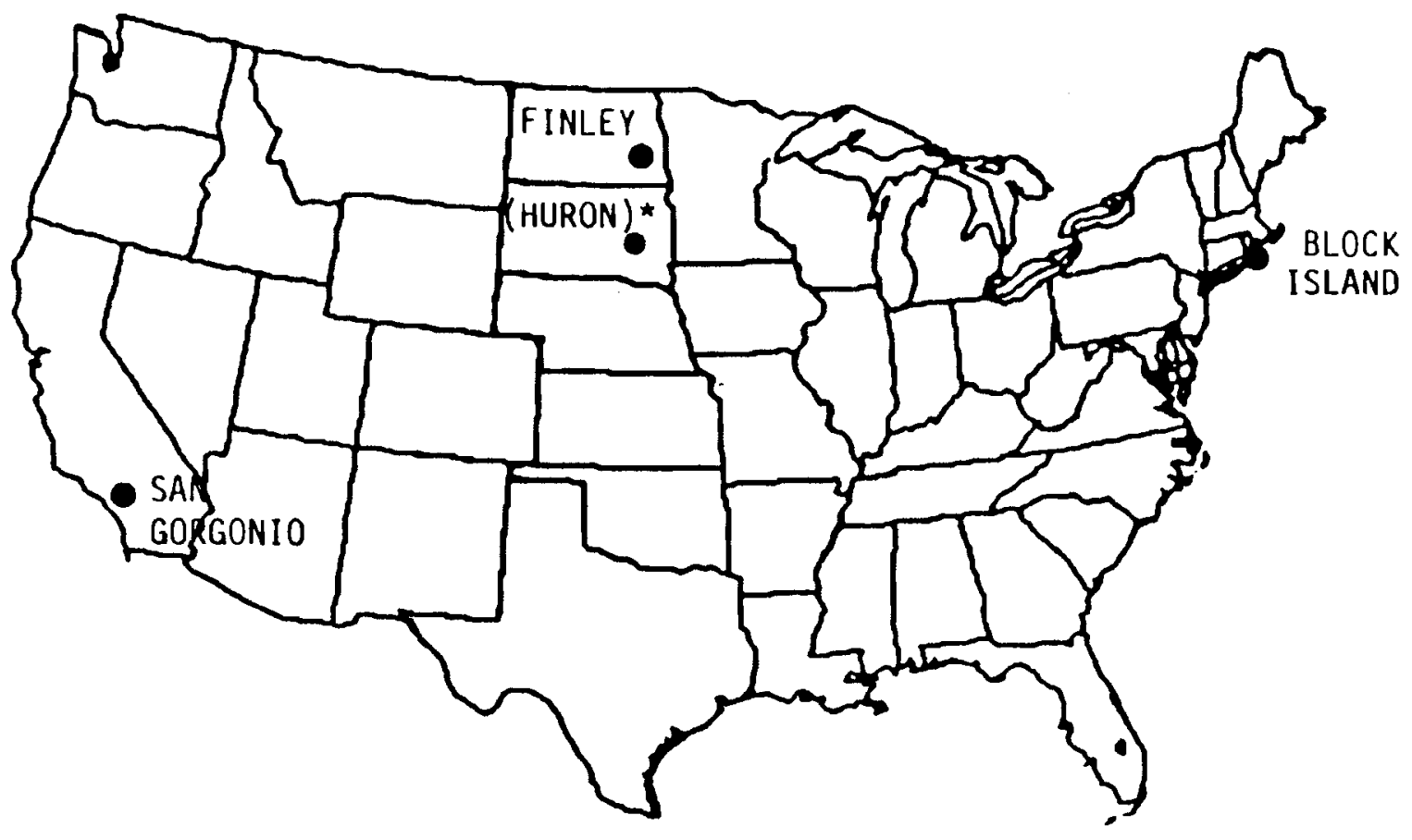

* Huron MOS forecasts were compared to Finley SO forecasts

FIGURE 3.1. Sites for Which Semiobjective and MOS Wind Forecasts were Compared 


\subsection{DETERMINISTIC POWER FORECAST VERIFICATION}

After developing the SPT model for speed-to-power conversion (Section 2), the first verification was performed in a deterministic sense; that is, forecast accuracy statistics were computed based upon a straightforward conversion of both the forecast and the observed wind speeds to MOD-2 power output. Least squares fits to histograms of the joint distribution of hourly average wind speed and equivalent MOD-2 power output were used for each site. The results are shown in Table 3.1 .

The table indicates that MOS forecasts are more accurate overall when attempting to predict hourly average power output values for the MOD-2 WTG. This is evidenced by the smaller mean absolute errors (MAE) and root mean square errors (RMSE) for MOS at each site and for all sites combined. The standard deviation values of the observations also show that the MOS forecasts are more accurate even when the power output is more variajle (thus more difficult to forecast).

One shortcoming of the MOS forecasts is their consistent negative bias. It is generally known that MOS tends to underfore:ast high wind speeds (Gilhousen 1980). To compensate for this an inflation technique (Klein, Lewis and Enger 1959) is employed to enlarge the variance of the forecasts to more closely approximate the observed wind speed distribution (the dependent data set), thereby better forecasting the more extreme values of wind speed. The negative bias in the MOS forecasts shows that the inflation technique does not entirely resolve the underforecasting problem. This could be an important consideration when using MOS for wind energy applications, because the more extreme speeds (those greater than $\sim 2$ standard deviations above the mean) are important for power production, but are not forecast well by M0:s.

The positive bias in the SO forecasts appears to be due to the fact that this is not a mature forecasting technique. The forecasters were in a learning mode and the forecasting guidelines were still being refined.

\subsection{SPT MODEL FORECAST VERIFICATION}

It is important that the wind power forecast verification results be interpreted in a way that is meaningful to the end usen, i.e., an electric utility. 
TABLE 3.1. Deterministic Verification of SO and MOS Power Output Forecasts

\begin{tabular}{|c|c|c|c|c|c|c|c|}
\hline \multirow[b]{2}{*}{ Site } & \multirow[b]{2}{*}{$\begin{array}{c}\text { Forecast } \\
\text { Type } \\
\end{array}$} & \multicolumn{6}{|c|}{ Hourly MOD-2 Power Forecast Verification (kW) } \\
\hline & & $\begin{array}{c}\text { Mean } \\
\text { Forecast }\end{array}$ & $\begin{array}{c}\text { Mean } \\
\text { Observed }\end{array}$ & $\begin{array}{l}\text { Std. Dev. } \\
\text { Observed }\end{array}$ & Bias & $\begin{array}{l}\text { Mean Abs. } \\
\text { Error }\end{array}$ & $\begin{array}{c}\text { RMS } \\
\text { Error } \\
\end{array}$ \\
\hline \multirow{2}{*}{ Block Island, RI } & MOS & 528 & 561 & 740 & -33 & 425 & 686 \\
\hline & so & 494 & 257 & 541 & +237 & 435 & 783 \\
\hline Huron, SD & MOS & 234 & 301 & 531 & -67 & 263 & 514 \\
\hline Finley, ND & so & 552 & 494 & 705 & +58 & 540 & 844 \\
\hline \multirow{2}{*}{ San Gorgonio, CA } & MOS & 854 & 951 & 962 & -97 & 686 & 1011 \\
\hline & so & 909 & 854 & 933 & +55 & 826 & 1141 \\
\hline \multirow{2}{*}{ All Sites } & MOS & 518 & 582 & 810 & -64 & 415 & 720 \\
\hline & so & 621 & 503 & 706 & +118 & 575 & 890 \\
\hline
\end{tabular}


The deterministic verification results shown in Section 3.1 are of interest to the meteorologist, but do not lend themselves well to interpretation by the forecast user. Consequently, in this section forecasts of the hourly average MOD-2 power output one would expect $90 \%$ of the tine (see Section 2) are made and verified for both the SO and MOS forecast sample. Results are shown in terms of the ability to predict whether or not the MOD-2 hourly average power output will be above or below one of four threshold levels: 600, 1200, 1800 and $2400 \mathrm{~kW}$.

The measure of forecasting skill used is the Heidke Skill Score (Brier and Allen 1952). It is defined in Figure 3.2. The Heidke Skill Score (SS) ranges from -1 (negative skill) to +1 (greatest possible skill). A SS of zero represents no skill above that of "chance guessing" based upon the climatological probability of occurrence of the event.

Forecast Wind Speeds

\begin{tabular}{|c|c|c|c|c|}
\hline & & Category 1 & Category 2 & Total \\
\hline \multirow{3}{*}{$\begin{array}{l}\text { Observed } \\
\text { Wind } \\
\text { Speeds }\end{array}$} & Category 1 & A & B & $x$ \\
\hline & Category 2 & C & $\bar{D}$ & $Y$ \\
\hline & Total & $\mathrm{L}$ & $M$ & $z$ \\
\hline
\end{tabular}

Heidke Skill Score $=\frac{(A+D)-\left(\left(X^{*} L\right)+\left(Y^{*} M\right)\right) / Z}{Z-\left(\left(X^{*} L\right)+\left(Y^{*} M\right)\right) / Z}$

FIGURE 3.2. Computation of the Heidke Skill Score

The measure of forecast reliability used is the probability of being correct (PC). The PC is the product of the $90 \%$ confidence level used and the fraction of forecasts that are correct with respect to the threshold power output level. For example, if $80 \%$ of the forecasts for a given threshold are correctly forecast for the $90 \%$ confidence SPT model, then there is an 0.72 probability $(0.9 \times 0.8)$ that the forecast would be correct.

A complete summary of SS and PC for the SO and MOS forecasts for a11 four sites examined is given in the Appendix. The remainder of this section is a 
brief summarization of the data in the Appendix. Comparisons of the MOS and SO forecasts are made with regard to both forecasting skill and reliability and their variability from site to site, with forecast projection time and with wind power category.

As described in Wegley and Formica (1983), the MOS and SO forecasts were 24-hr hourly average wind speed forecasts produced twice daily. The periods for which forecasts were valid were 0600-0600 GMT and 1800-1800 GMT each day. Table 3.2 provides comparison of MOS and SO forecasts for the four sites included in the study and with the 0600 and 1800 GMT forecasts combined.

TABLE 3.2. Site-to-Site Comparison of MOS and SO Hourly MOD-2 Power Forecasts - All Forecast Times and Power Categories Combined

\begin{tabular}{lcccc}
\multicolumn{1}{c}{ Site } & $\begin{array}{c}\text { Forecast } \\
\text { Type }\end{array}$ & PC & SS \\
Block Island, RI & SO & & 0.788 & 0.423 \\
Finley, ND & MOS & & 0.734 & 0.424 \\
Huron, SD & SO & & 0.733 & 0.357 \\
San Gorgonio, CA & MOS & 0.806 & 0.479 \\
& SO & & 0.658 & 0.418 \\
& MOS & 0.776 & 0.421
\end{tabular}

The probability of forecasting any power category correctly at any projection into the future varies from a low of $\sim 0.66$ at San Gorgonio (SO) to a high of $\sim 0.81$ at Huron (MOS). These data show that the user of such forecasts can be $\sim 75 \%$ confident that the power output forecast will be correct; but, the actual accuracy is site specific. The MOS forecasts perform more reliably at San Gorgonio while the SO forecasts are more reliable at Block Island. There is considerable evidence that the comparison between Finley and Huron is not an equitable one. Figure 2.1 shows a very large different between the SPT models for these two sites. This can only be attributed to significant differences between the wind characteristics of the two sites. Though verification data will be presented for these two sites, inferences about the 
relative performance of MOS and SO forecasts should not be drawn based upon comparisons of Finley and Huron alone. No attempt was made to develop a normalization scheme for comparison of these sites due to the extreme complexity of that task.

At the site where both MOS and SO forecasts were made (Block Island and San Gorgonio), forecasting skill is nearly constant and the skill scores are moderately high $(>0.4)$ at all sites except Finley. The low skill score at Finley is a bit deceiving. It can be primarily a:tributed to the inability to accurately forecast the relatively rare power category of $>2400 \mathrm{~kW}$. Examination of Figure 2.1 reveals that this power category occurs only when hourly wind speeds fall between 15.5 and $17.0 \mathrm{~m} / \mathrm{s}$. This is a very narrow wind speed interval, which seldom occurs and thus is difficult to forecast.

Comparisons of MOS and SO forecasting reliability and skill as a function of projection time are given in Table 3.3. For Block Island the SO appear more reliable than MOS at all projection times. The MOS forecasts exhibit slightly higher skill in the first 12 hours and while the so forecasts are more skillful in the 13-24 hour range. It is interesting to note that the SO forecasts compare favorably with MOS forecasts though the forecasters using the SO approach were still in a learning mode (Wegley and Formica 1983). The results shown in Table 3.3 for Block Island can not be inferred from the deterministic verification presented in Table 3.1. Thus, if categorical forecasts are required, they should be verified as such in order to properly interpret their accuracy and reliability.

The comparisons of Huron MOS to Finley SO forecasts in Table 3.3 indicate that MOS is more reliable at all projections and more skillful than the SO forecasts in 211 but the first 6 hours of the forecast. The relatively rapid deterioration of the skill of the so forecasts with t'me is notable at Finley.

It is not possible to fully explain this relatively poorer performance of the SO forecasts because Finley and Huron are not co-located.

The comparison between MOS and SO forecasts for San Gorgonio in Table 3.3 is very similar to that for Huron and Finley. The primary difference is in the SO skill scores which do not deteriorate as rapidly for San Gorgonio as for Finley. 
TABLE 3.3. Comparison of Hourly MOD-2 Wind Power Forecast Reliability and Skill as a Function of Projection Time

Block Is Tand 0600 and 1800 GMT Forecasts

\begin{tabular}{|c|c|c|c|c|}
\hline \multirow{2}{*}{$\begin{array}{c}\text { Projection } \\
\text { Time } \\
\text { (Hrs) } \\
\end{array}$} & \multicolumn{2}{|c|}{ PC } & \multicolumn{2}{|c|}{ SS } \\
\hline & MOS & SO & MOS & SO \\
\hline $1-6$ & 0.747 & 0.826 & 0.530 & 0.489 \\
\hline $7-12$ & 0.725 & 0.788 & 0.436 & 0.410 \\
\hline $13-18$ & 0.713 & 0.791 & 0.385 & 0.462 \\
\hline $19-24$ & 0.719 & 0.747 & 0.345 & 0.362 \\
\hline
\end{tabular}

Huron (MOS), Finley (SO) 0600 and 1800 GMT Forecasts

Projection

Time

(Hrs)
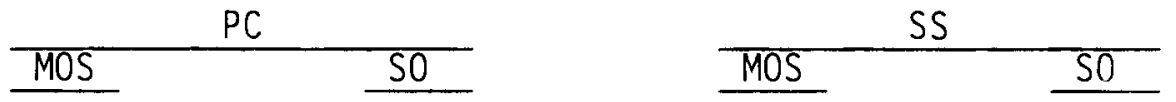

$1-6$

0.810

0.796

0.526

0.596

$7-12$

0.811

0.726

0.463

0.338

$13-18$

0.797

0.703

0.448

0.225

19-24

0.806

0.709

0.467

0.269

San Gorgonio 0600 and 1800 GMT Forecasts

Projection

\begin{tabular}{c} 
Time \\
(Hrs) \\
\hline
\end{tabular}

\begin{tabular}{ll}
$\mathrm{PC}$ \\
\hline $\mathrm{MOS}$ & $\mathrm{SO}$ \\
\hline
\end{tabular}

1-6

0.783

0.692

0.785

0.652

0.765

0.652

0.769

0.636

\begin{tabular}{ll}
\multicolumn{2}{c}{ SS } \\
\hline MOS & SO \\
\hline 0.455 & 0.514 \\
0.447 & 0.402 \\
0.402 & 0.396 \\
0.341 & 0.354
\end{tabular}


TABLE 3.4. Comparison of Hourly MOD-2 Wind Power Forecast Reliability as a Function of Power Output Category

Block Island 0600 and 1800 GMT Forecasts

\begin{tabular}{c}
$\begin{array}{c}\text { Power Output } \\
\text { Category } \\
(\mathrm{kW})\end{array}$ \\
\hline$>600$ \\
$>1200$ \\
$>1800$ \\
$>2400$
\end{tabular}

\begin{tabular}{ccc}
\multicolumn{2}{c}{$P C$} & \\
\hline MOS & & S0 \\
\hline 0.693 & & 0.716 \\
0.704 & & 0.753 \\
0.774 & & 0.806 \\
--- & & 0.876
\end{tabular}

\begin{tabular}{lll}
\multicolumn{2}{c}{ SS } & \\
\hline MOS & & SO \\
\hline 0.466 & & 0.413 \\
0.376 & & 0.409 \\
0.308 & & 0.342 \\
--- & & 0.212
\end{tabular}

Huron (MOS), Finley (SO) 0600 And 1800 GMT Forecasts

\begin{tabular}{|c|c|c|c|c|}
\hline \multirow{2}{*}{$\begin{array}{l}\text { Power Output } \\
\text { Category } \\
\text { (kW) }\end{array}$} & \multicolumn{2}{|c|}{$\mathrm{PC}$} & \multicolumn{2}{|c|}{ SS } \\
\hline & MOS & S0 & MOS & 50 \\
\hline$>600$ & 0.765 & 0.631 & 0.529 & 0.311 \\
\hline$>1200$ & 0.808 & 0.680 & 0.420 & 0.301 \\
\hline$>1800$ & 0.847 & 0.755 & 0.226 & 0.276 \\
\hline$>2400$ & --- & 0.867 & --- & 0.275 \\
\hline
\end{tabular}

San Gorgonio 0600 and 1800 GMT Forecasts

Power Output

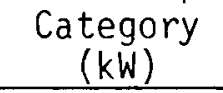

\begin{tabular}{lll} 
& PC & \\
\hline MOS & & S0 \\
\hline 0.689 & & 0.615 \\
0.729 & & 0.624 \\
0.805 & & 0.642 \\
0.882 & & 0.753
\end{tabular}

\begin{tabular}{lll}
\multicolumn{2}{c}{ SS } & \\
\hline MOS & & S0 \\
\hline 0.409 & & 0.367 \\
0.372 & & 0.380 \\
0.297 & & 0.363 \\
-0.006 & & 0.285
\end{tabular}

Table 3.4 compares the accuracy and skill of the wind power forecasts as a function of power output category. The power calegories are based upon threshold wind speeds which, if exceeded, indicate $90 \%$ confidence that the hourly average power threshold will be exceeded. The trend at all sites is for 
increasing probabilities of being correct with increasing power output category. This trend is easily interpreted. The higher the power output category the more rare the event. Therefore a "NO" for the power category is usually forecast and is usually correct. Since such forecasting is not significantly better than climatology the skill scores for the higher power categories are generally low (they actually become negative for MOS at San Gorgonio). The fact that the MOS forecasts deteriorate more rapidly than So forecasts with increasing power output reflects the inability of MOS (in the form used in this study) to forecast rare events well. If MOS is used in the future for categorical wind power forecasts it is recommended that probabilistic forecasts be used and that threshold probabilities be determined based upon cost/loss to the user. In this manner compensation for the tendency of MOS forecasts to cluster about the mean can be made. 


\subsection{CONCLUSIONS AND RECOMMENDATIONS}

The fact that categorical forecasts of power output averaged $\sim 75 \%$ probability of being correct and that skill scores averaged $\sim 0.40$ for a 24 -hour forecast period is encouraging. However, the results of this study (as shown in Section 3 and the Appendix) are an approximate measure of the lower bound of the ability to forecast hourly WTG performance using state-of-the-art wind forecasting techniques. Any further work in wind forecasting in WTG operations should only be undertaken when appropriate data in sufficient quantity have been collected specifically for such studies. In the past, the quantity and quality of existing data have been the primary limiting factor in wind forecasting for wind energy applications (Wegley and Formica 1983, GiThousen 1980, Bodin and Fredriksson 1981). In addition, future work should concentrate upon shorter time frames and on clusters of WTGs in order to help address loadfrequency control problems that could occur when wind energy is used on a large scale.

As utility and WTG operating strategies are examined further, it may become desirable to change the format of 24-hour wind power forecasts. The difference between the results of deterministic and categorical forecast verification (shown in Section 3) serve as a warning that wind power forecasts should be verified in a manner that measures their accuracy and reliability as viewed by the end user who knows how the forecasts will be incorporated into his operations.

The static probabilistic transformation model used in this study could be improved by developing regression models. The models would be based upon the frequency of occurrence of wind speed fluctuations on time scales that would cause interaction with the individual WTG operating strategy. Such analyses would probably be based upon spectral characteristics of the wind at a site and could possibly be used to develop more widely applicable performance models for use at sites where high-speed wind data are not available. These analyses could prove to be a site-screening technique that would be useful in the early stages of wind energy feasibility studies. 


\subsection{REFERENCES}

Bodin, S. and U. Fredriksson. 1981. Uncertainty in Wind Forecasting for Wind Power Networks. RMK 25, Swedish Meteorological and Hydrological Institute, Norrkoping, Sweden.

Brier, G. W. and R. A. Allen. 1952. "Verification of Weather Forecasts." In Compendium of Meteorology. pp. 841-848, American Meteorological Society, Boston, Massachusetts.

Gilhousen, D. B. 1980. Development and Testing of Model Output Statistics for Wind Forecasts at Wind Turbine Generator Sites. DOE/RL/10046-1, Techniques Development Laboratory, National Weather Service, NOAA, Silver Spring, Maryland.

Goldenblatt, M. K., H. L. Wegley and A. H. Miller. 1983. Analys is of the Effects of Integrating Wind Turbines Into a Conventional Utility: A Case Study. PNL-3962 REV., Pacific Northwest Laboratory, Richland, Washington.

Klein, W. H., B. M. Lewis and I. Enger. 1959. "Objective Prediction of Five-Day Mean Temperature During Winter." Journal of Meteorology. 16:672-682.

Lee, S. T. and Z. A. Yamayee. 1981. "Load-Following and Spinning-Reserve Penalties for Intermittent Generation." IEEE Transactions on Power Apparatus and Systems. Vol. PAS-100, No. 3, pp. 1203-1211.

Miller, A. H. and W. J. Formica. 1984. Development and Verification of MOD-2 and MOD-OA Simulation Mode1s. PNL-4864, Pacific Northwest Laboratory, Richland, Washington.

Pennel1, W. T. and A. H. Miller. 1982. Procedures for Modeling Wind Turbine Performance From Site Wind Data. 82-Pet-7, American Society of Mechanical Engineers, New York, New York.

Reddoch, T. W. P. R. Barnes, J. S. Lawler and J. C. Skroski. 1981. "Operational Concepts for Large Wind Turbine Arrays." Proceedings of Fifth Biennial Wind Energy Conference and Workshop (WWV). SERI/CP-635-1340, Solar Energy Research Institute, Golden, Colorado.

Schlueter, R. A., G. L. Park and R. Bouwmeester. 1983. Power System Operation With Wind Arrays. OR0-7405-1 Final Report to the Department of Energy Oak Ridge National Laboratory, Oak Ridge, Tennessee.

Wegley, H. L. 1982. "The Development and Evaluation of Wind Forecasts for Wind Energy Applications." Preprints 9th Conference on Weather Forecasting and Analysis. American Meteorological Society, Boston, Massachusetts.

Wegley, H. L. and W. J. Formica. 1983. Test Application of a Semiobjective Approach to Wind Forecasting for Wind Energy Applications. PNL-4403, Pacific Northwest Laboratory, Richland, Washington. 

APPENDIX A 
The following tables contain listings of all skill score and probability of being correct results from verification of MOD-2 hourly power output forecasts (using the SPT model) for four sites and two forecasting techniques (semiobjective [SO] and model output statistics [MOS]). For each site a table is provided showing the wind speed threshold value above which there is $90 \%$ confidence of obtaining at least the specified hourly average power output. The speed thresholds were developed for each site by using 1 year of dependent data for the site and analyzing it as described in Section 2 of this report.

TABLE A.1. 90\% Confidence SPT Model Hourly Average Speed Values for Block Island, RI

\begin{tabular}{c}
$\begin{array}{c}\text { M0D-2 Power } \\
\text { Category } \\
(\mathrm{kW})\end{array}$ \\
\hline$>600$ \\
$>1200$ \\
$>1800$ \\
$>2400$
\end{tabular}

90\% Confidence Wind Speed Threshold (m/s)

9.4

10.4

11.7

(a)

(a) Power output cannot be equated to any hourly average speed with $90 \%$ confidence 
TABLE A.2 Semiobjective SPT Wind Power Forecast Verification for Block Island, RI

0600 GMT Forecasts

\begin{tabular}{|c|c|c|c|c|c|c|}
\hline \multirow{2}{*}{$\begin{array}{l}\text { Projection } \\
\text { Time } \\
\text { (Hrs) } \\
\end{array}$} & \multirow{2}{*}{$\begin{array}{l}\text { Verification }(a) \\
\text { Statistic } \\
\end{array}$} & \multicolumn{5}{|c|}{ Power Category $(\mathrm{kW})$} \\
\hline & & $>600$ & $>1200$ & $\geq 1800$ & $>2400$ & ALL \\
\hline $1-6$ & $\begin{array}{l}\text { PC } \\
\text { SS }\end{array}$ & $\begin{array}{l}0.781 \\
0.421\end{array}$ & $\begin{array}{l}0.821 \\
0.452\end{array}$ & $\begin{array}{l}0.865 \\
0.481\end{array}$ & $\begin{array}{l}0.900 \\
1.000\end{array}$ & $\begin{array}{l}0.842 \\
0.461\end{array}$ \\
\hline $7-12$ & $\begin{array}{l}P C \\
S S\end{array}$ & $\begin{array}{l}0.703 \\
0.323\end{array}$ & $\begin{array}{l}0.720 \\
0.201\end{array}$ & $\begin{array}{r}0.779 \\
-0.008\end{array}$ & $\begin{array}{l}0.900 \\
1.000\end{array}$ & $\begin{array}{l}0.775 \\
0.266\end{array}$ \\
\hline $13-18$ & $\begin{array}{l}\text { PC } \\
\text { SS }\end{array}$ & $\begin{array}{l}0.719 \\
0.489\end{array}$ & $\begin{array}{l}0.770 \\
0.479\end{array}$ & $\begin{array}{l}0.770 \\
0.264\end{array}$ & $\begin{array}{l}0.879 \\
0.276\end{array}$ & $\begin{array}{l}0.784 \\
0.468\end{array}$ \\
\hline $18-24$ & $\begin{array}{l}\text { PC } \\
\text { SS }\end{array}$ & $\begin{array}{l}0.659 \\
0.336\end{array}$ & $\begin{array}{l}0.704 \\
0.350\end{array}$ & $\begin{array}{l}0.820 \\
0.502\end{array}$ & $\begin{array}{l}0.846 \\
0.115\end{array}$ & $\begin{array}{l}0.757 \\
0.393\end{array}$ \\
\hline ALL & $\begin{array}{l}P C \\
S S\end{array}$ & $\begin{array}{l}0.716 \\
0.398\end{array}$ & $\begin{array}{l}0.753 \\
0.370\end{array}$ & $\begin{array}{l}0.807 \\
0.304\end{array}$ & $\begin{array}{l}0.882 \\
0.181\end{array}$ & $\begin{array}{l}0.790 \\
0.400\end{array}$ \\
\hline
\end{tabular}

1800 GMT Forecasts

\begin{tabular}{|c|c|c|c|c|c|c|}
\hline \multirow{2}{*}{$\begin{array}{l}\text { Projection } \\
\text { Time } \\
\text { (Hrs) } \\
\end{array}$} & \multirow{2}{*}{$\begin{array}{l}\text { Verification } \\
\text { Statistic } \\
\end{array}$} & \multicolumn{5}{|c|}{ Power Category $(\mathrm{kW})$} \\
\hline & & 2600 & $>1200$ & $>1800$ & $>2400$ & ALL \\
\hline $1-6$ & $\begin{array}{l}\text { PC } \\
\text { SS }\end{array}$ & $\begin{array}{l}0.686 \\
0.346\end{array}$ & $\begin{array}{l}0.802 \\
0.516\end{array}$ & $\begin{array}{l}0.860 \\
0.667\end{array}$ & $\begin{array}{l}0.896 \\
0.664\end{array}$ & $\begin{array}{l}0.799 \\
0.510\end{array}$ \\
\hline $7-12$ & $\begin{array}{l}\text { PC } \\
\text { SS }\end{array}$ & $\begin{array}{l}0.753 \\
0.516\end{array}$ & $\begin{array}{l}0.763 \\
0.514\end{array}$ & $\begin{array}{l}0.834 \\
0.591\end{array}$ & $\begin{array}{l}0.857 \\
0.378\end{array}$ & $\begin{array}{l}0.802 \\
0.538\end{array}$ \\
\hline $13-18$ & $\begin{array}{l}P C \\
S S\end{array}$ & $\begin{array}{l}0.757 \\
0.516\end{array}$ & $\begin{array}{l}0.767 \\
0.486\end{array}$ & $\begin{array}{l}0.807 \\
0.205\end{array}$ & $\begin{array}{l}0.866 \\
0.000\end{array}$ & $\begin{array}{l}0.799 \\
0.455\end{array}$ \\
\hline $18-24$ & $\begin{array}{l}P C \\
S S\end{array}$ & $\begin{array}{l}0.678 \\
0.386\end{array}$ & $\begin{array}{l}0.683 \\
0.324\end{array}$ & $\begin{array}{l}0.719 \\
0.152\end{array}$ & $\begin{array}{l}0.864 \\
0.000\end{array}$ & $\begin{array}{l}0.736 \\
0.334\end{array}$ \\
\hline ALL & $\begin{array}{l}\text { PC } \\
\text { SS }\end{array}$ & $\begin{array}{l}0.717 \\
0.429\end{array}$ & $\begin{array}{l}0.754 \\
0.446\end{array}$ & $\begin{array}{l}0.805 \\
0.377\end{array}$ & $\begin{array}{l}0.871 \\
0.232\end{array}$ & $\begin{array}{l}0.787 \\
0.446\end{array}$ \\
\hline
\end{tabular}

0600 and 1800 GMT Forecast.s

\begin{tabular}{|c|c|c|c|c|c|c|}
\hline $\begin{array}{l}\text { Projection } \\
\text { Time } \\
\text { (Hrs) }\end{array}$ & $\begin{array}{c}\text { Verification }(a) \\
\text { Statistic }\end{array}$ & 2600 & $\begin{array}{l}\text { Power } \\
>1200\end{array}$ & $\frac{\text { Category }}{>1800}$ & $\frac{(\mathrm{kW})}{>2400}$ & $\overline{\mathrm{ALL}}$ \\
\hline $1-6$ & $\begin{array}{l}P C \\
S S\end{array}$ & $\begin{array}{l}0.734 \\
0.387\end{array}$ & $\begin{array}{l}0.811 \\
0.491\end{array}$ & $\begin{array}{l}0.862 \\
0.600\end{array}$ & $\begin{array}{l}0.898 \\
0.666\end{array}$ & $\begin{array}{l}0.826 \\
0.489\end{array}$ \\
\hline $7-12$ & $\begin{array}{l}\text { PC } \\
\text { SS }\end{array}$ & $\begin{array}{l}0.727 \\
0.416\end{array}$ & $\begin{array}{l}0.740 \\
0.367\end{array}$ & $\begin{array}{l}0.804 \\
0.319\end{array}$ & $\begin{array}{l}0.880 \\
0.390\end{array}$ & $\begin{array}{l}0.788 \\
0.410\end{array}$ \\
\hline $13-18$ & $\begin{array}{l}\text { PC } \\
\text { SS }\end{array}$ & $\begin{array}{l}0.737 \\
0.500\end{array}$ & $\begin{array}{l}0.768 \\
0.481\end{array}$ & $\begin{array}{l}0.787 \\
0.246\end{array}$ & $\begin{array}{l}0.873 \\
0.135\end{array}$ & $\begin{array}{l}0.791 \\
0.462\end{array}$ \\
\hline $18-24$ & $\begin{array}{l}P C \\
S S\end{array}$ & $\begin{array}{l}0.669 \\
0.361\end{array}$ & $\begin{array}{l}0.694 \\
0.336\end{array}$ & $\begin{array}{l}0.770 \\
0.300\end{array}$ & $\begin{array}{l}0.856 \\
0.073\end{array}$ & $\begin{array}{l}0.747 \\
0.362\end{array}$ \\
\hline ALL & $\begin{array}{l}\text { PC } \\
\text { SS }\end{array}$ & $\begin{array}{l}0.716 \\
0.413\end{array}$ & $\begin{array}{l}0.753 \\
0.409\end{array}$ & $\begin{array}{l}0.806 \\
0.342\end{array}$ & $\begin{array}{l}0.876 \\
0.212\end{array}$ & $\begin{array}{l}0.788 \\
0.423\end{array}$ \\
\hline
\end{tabular}

(a) $P C=$ probability of being correct

SS = Heidke Skill Score (defined in Section 3) 
TABLE A.3. MOS SPT Wind Power Forecast Verification for Block Island, RI

0600 GMT Forecasts

\begin{tabular}{|c|c|c|c|c|c|c|}
\hline $\begin{array}{l}\text { Projection } \\
\text { Time }\end{array}$ & Verification (a) & & & Catego & $(\mathrm{kW})$ & \\
\hline (Hrs) & Statistic & $>600$ & $>1200$ & $>1800$ & $>2400$ & ALL \\
\hline $1-6$ & $\begin{array}{l}\text { PC } \\
\text { SS }\end{array}$ & $\begin{array}{l}0.728 \\
0.532\end{array}$ & $\begin{array}{l}0.750 \\
0.424\end{array}$ & $\begin{array}{l}0.795 \\
0.236\end{array}$ & --- & $\begin{array}{l}0.758 \\
0.468\end{array}$ \\
\hline $7-12$ & $\begin{array}{l}\text { PC } \\
\text { SS }\end{array}$ & $\begin{array}{l}0.705 \\
0.518\end{array}$ & $\begin{array}{l}0.720 \\
0.455\end{array}$ & $\begin{array}{l}0.742 \\
0.223\end{array}$ & --- & $\begin{array}{l}0.722 \\
0.456\end{array}$ \\
\hline $13-18$ & $\begin{array}{l}\text { PC } \\
\text { SS }\end{array}$ & $\begin{array}{l}0.669 \\
0.220\end{array}$ & $\begin{array}{l}0.682 \\
0.377\end{array}$ & $\begin{array}{l}0.758 \\
0.394\end{array}$ & -- & $\begin{array}{l}0.688 \\
0.340\end{array}$ \\
\hline $18-24$ & $\begin{array}{l}\text { PC } \\
\text { SS }\end{array}$ & $\begin{array}{l}0.615 \\
0.136\end{array}$ & $\begin{array}{l}0.645 \\
0.086\end{array}$ & $\begin{array}{r}0.780 \\
-0.053\end{array}$ & --- & $\begin{array}{l}0.680 \\
0.121\end{array}$ \\
\hline ALL & $\begin{array}{l}P C \\
\text { SS }\end{array}$ & $\begin{array}{l}0.658 \\
0.364\end{array}$ & $\begin{array}{l}0.707 \\
0.380\end{array}$ & $\begin{array}{l}0.767 \\
0.271\end{array}$ & --- & $\begin{array}{l}0.711 \\
0.373\end{array}$ \\
\hline
\end{tabular}

1800 GMT Forecasts

\begin{tabular}{|c|c|c|c|c|c|c|}
\hline \multirow{2}{*}{$\begin{array}{l}\text { Projection } \\
\text { Time } \\
\text { (Hrs) } \\
\end{array}$} & Verification (a) & \multicolumn{5}{|c|}{ Power Category (kW) } \\
\hline & Statistic & $>600$ & $>1200$ & $>1800$ & $\geq 2400$ & ALL \\
\hline $1-6$ & $\begin{array}{l}\text { PC } \\
\text { SS }\end{array}$ & $\begin{array}{l}0.726 \\
0.594\end{array}$ & $\begin{array}{l}0.703 \\
0.452\end{array}$ & $\begin{array}{l}0.766 \\
0.426\end{array}$ & --- & $\begin{array}{l}0.732 \\
0.528\end{array}$ \\
\hline $7-12$ & $\begin{array}{l}\text { PC } \\
\text { SS }\end{array}$ & $\begin{array}{l}0.699 \\
0.473\end{array}$ & $\begin{array}{l}0.728 \\
0.386\end{array}$ & $\begin{array}{l}0.756 \\
0.196\end{array}$ & --- & $\begin{array}{l}0.728 \\
0.408\end{array}$ \\
\hline $13-18$ & $\begin{array}{l}\text { PC } \\
\text { SS }\end{array}$ & $\begin{array}{l}0.718 \\
0.531\end{array}$ & $\begin{array}{l}0.687 \\
0.280\end{array}$ & $\begin{array}{l}0.774 \\
0.123\end{array}$ & --- & $\begin{array}{l}0.726 \\
0.402\end{array}$ \\
\hline $18-24$ & $\begin{array}{l}P C \\
S S\end{array}$ & $\begin{array}{l}0.691 \\
0.462\end{array}$ & $\begin{array}{l}0.675 \\
0.338\end{array}$ & $\begin{array}{l}0.788 \\
0.464\end{array}$ & --- & $\begin{array}{l}0.718 \\
0.433\end{array}$ \\
\hline ALL & $\begin{array}{l}P C \\
S S\end{array}$ & $\begin{array}{l}0.712 \\
0.529\end{array}$ & $\begin{array}{l}0.700 \\
0.373\end{array}$ & $\begin{array}{l}0.796 \\
0.332\end{array}$ & --- & $\begin{array}{l}0.741 \\
0.466\end{array}$ \\
\hline
\end{tabular}

0600 and 1800 GMT Forecasts

\begin{tabular}{|c|c|c|c|c|c|c|}
\hline $\begin{array}{l}\text { Projection } \\
\text { Time } \\
\text { (Hrs) }\end{array}$ & Verification (a) & & $\frac{\text { Pon }}{>1200}$ & Categor & $\frac{(\mathrm{kw})}{32000}$ & \\
\hline & Statistic & $>600$ & $>1200$ & $>1800$ & 22400 & ALL \\
\hline $1-6$ & $\begin{array}{l}\text { PC } \\
\text { SS }\end{array}$ & $\begin{array}{l}0.727 \\
0.569\end{array}$ & $\begin{array}{l}0.727 \\
0.448\end{array}$ & $\begin{array}{l}0.781 \\
0.361\end{array}$ & --- & $\begin{array}{l}0.747 \\
0.530\end{array}$ \\
\hline $7-12$ & $\begin{array}{l}\text { PC } \\
\text { SS }\end{array}$ & $\begin{array}{l}0.702 \\
0.500\end{array}$ & $\begin{array}{l}0.723 \\
0.429\end{array}$ & $\begin{array}{l}0.749 \\
0.213\end{array}$ & --- & $\begin{array}{l}0.725 \\
0.436\end{array}$ \\
\hline $13-18$ & $\begin{array}{l}\text { PC } \\
\text { SS }\end{array}$ & $\begin{array}{l}0.668 \\
0.389\end{array}$ & $\begin{array}{l}0.685 \\
0.334\end{array}$ & $\begin{array}{l}0.786 \\
0.362\end{array}$ & --- & $\begin{array}{l}0.713 \\
0.385\end{array}$ \\
\hline $18-24$ & $\begin{array}{l}P C \\
S S\end{array}$ & $\begin{array}{l}0.652 \\
0.310\end{array}$ & $\begin{array}{l}0.660 \\
0.223\end{array}$ & $\begin{array}{l}0.784 \\
0.276\end{array}$ & --- & $\begin{array}{l}0.719 \\
0.345\end{array}$ \\
\hline ALL & $\begin{array}{l}P C \\
S S\end{array}$ & $\begin{array}{l}0.693 \\
0.466\end{array}$ & $\begin{array}{l}0.704 \\
0.376\end{array}$ & $\begin{array}{l}0.7 i \pi \\
0.308\end{array}$ & -- & $\begin{array}{l}0.734 \\
0.424\end{array}$ \\
\hline
\end{tabular}

(a) $P C=$ probability of being correct

SS = Heidke Skill Score (defined in Section 3) 
TABLE A.4. $90 \%$ Confidence SPT Model Hourly Average Speed Values for Finley, ND

\begin{tabular}{c}
$\begin{array}{c}\text { MOD-2 Power } \\
\text { Category } \\
(\mathrm{kW})\end{array}$ \\
\hline$>600$ \\
$>1200$ \\
$>1800$ \\
$>2400$
\end{tabular}

90\% Confidence Wind Speed

Threshold (m/s)

10.0

11.2

12.5

15.2 
TABLE A.5. Semiobjective SPT Wind Power Forecast Verification for Finley, ND

0600 GMT Forecasts

\begin{tabular}{|c|c|c|c|c|c|c|}
\hline $\begin{array}{l}\text { Projection } \\
\text { Time }\end{array}$ & Verification (a) & & & Categor & $(\mathrm{kW})$ & \\
\hline (Hrs) & Statistic & $>600$ & $>1200$ & $>1800$ & $\geq 2400$ & $\overline{\mathrm{ALL}}$ \\
\hline $1-6$ & $\begin{array}{l}\text { PC } \\
\text { SS }\end{array}$ & $\begin{array}{l}0.716 \\
0.486\end{array}$ & $\begin{array}{l}0.761 \\
0.497\end{array}$ & $\begin{array}{l}0.814 \\
0.503\end{array}$ & $\begin{array}{l}0.879 \\
0.620\end{array}$ & $\begin{array}{l}0.793 \\
0.533\end{array}$ \\
\hline $7-12$ & $\begin{array}{l}P C \\
S S\end{array}$ & $\begin{array}{l}0.653 \\
0.362\end{array}$ & $\begin{array}{l}0.700 \\
0.301\end{array}$ & $\begin{array}{l}0.766 \\
0.176\end{array}$ & $\begin{array}{r}0.854 \\
-0.020\end{array}$ & $\begin{array}{l}0.743 \\
0.349\end{array}$ \\
\hline $13-18$ & $\begin{array}{l}P C \\
S S\end{array}$ & $\begin{array}{l}0.598 \\
0.268\end{array}$ & $\begin{array}{l}0.652 \\
0.224\end{array}$ & $\begin{array}{l}0.714 \\
0.122\end{array}$ & $\begin{array}{l}0.879 \\
0.000\end{array}$ & $\begin{array}{l}0.711 \\
0.298\end{array}$ \\
\hline $18-24$ & $\begin{array}{l}\text { PC } \\
\text { SS }\end{array}$ & $\begin{array}{l}0.663 \\
0.403\end{array}$ & $\begin{array}{l}0.663 \\
0.314\end{array}$ & $\begin{array}{l}0.718 \\
0.238\end{array}$ & $\begin{array}{r}0.857 \\
-0.016\end{array}$ & $\begin{array}{l}0.725 \\
0.373\end{array}$ \\
\hline ALL & $\begin{array}{l}\text { PC } \\
\text { SS }\end{array}$ & $\begin{array}{l}0.658 \\
0.378\end{array}$ & $\begin{array}{l}0.694 \\
0.329\end{array}$ & $\begin{array}{l}0.753 \\
0.253\end{array}$ & $\begin{array}{l}0.867 \\
0.196\end{array}$ & $\begin{array}{l}0.743 \\
0.384\end{array}$ \\
\hline
\end{tabular}

1800 GMT Forecasts

\begin{tabular}{|c|c|c|c|c|c|c|}
\hline $\begin{array}{l}\text { Projection } \\
\text { Time } \\
\text { (hrs) }\end{array}$ & $\begin{array}{c}\text { Verification } \\
\text { Statistic }\end{array}$ & $>600$ & $\begin{array}{l}\text { Power } \\
>1200\end{array}$ & $\frac{\text { Category }}{>1800}$ & $\frac{(\mathrm{kW})}{>2400}$ & $\overline{A L L}$ \\
\hline $1-6$ & $\begin{array}{l}\text { PC } \\
\text { SS }\end{array}$ & $\begin{array}{l}0.742 \\
0.621\end{array}$ & $\begin{array}{l}0.752 \\
0.574\end{array}$ & $\begin{array}{l}0.813 \\
0.639\end{array}$ & $\begin{array}{l}0.887 \\
0.743\end{array}$ & $\begin{array}{l}0.799 \\
0.649\end{array}$ \\
\hline $7-12$ & $\begin{array}{l}\text { PC } \\
\text { SS }\end{array}$ & $\begin{array}{l}0.594 \\
0.236\end{array}$ & $\begin{array}{l}0.647 \\
0.264\end{array}$ & $\begin{array}{l}0.736 \\
0.290\end{array}$ & $\begin{array}{l}0.853 \\
0.417\end{array}$ & $\begin{array}{l}0.708 \\
0.325\end{array}$ \\
\hline $13-18$ & $\begin{array}{l}\text { PC } \\
\text { SS }\end{array}$ & $\begin{array}{l}0.535 \\
0.023\end{array}$ & $\begin{array}{l}0.633 \\
0.090\end{array}$ & $\begin{array}{l}0.743 \\
0.101\end{array}$ & $\begin{array}{r}0.872 \\
-0.006\end{array}$ & $\begin{array}{l}0.696 \\
0.136\end{array}$ \\
\hline $18-24$ & $\begin{array}{l}\text { PC } \\
\text { SS }\end{array}$ & $\begin{array}{l}0.539 \\
0.046\end{array}$ & $\begin{array}{l}0.632 \\
0.110\end{array}$ & $\begin{array}{l}0.738 \\
0.035\end{array}$ & $\begin{array}{r}0.856 \\
-0.020\end{array}$ & $\begin{array}{l}0.691 \\
0.138\end{array}$ \\
\hline ALL & $\begin{array}{l}\text { PC } \\
\text { SS }\end{array}$ & $\begin{array}{l}0.602 \\
0.239\end{array}$ & $\begin{array}{l}0.666 \\
0.271\end{array}$ & $\begin{array}{l}0.757 \\
0.300\end{array}$ & $\begin{array}{l}0.867 \\
0.345\end{array}$ & $\begin{array}{l}0.723 \\
0.328\end{array}$ \\
\hline
\end{tabular}

0600 and 1800 GMT Forecasts

\begin{tabular}{|c|c|c|c|c|c|c|}
\hline $\begin{array}{l}\text { Projection } \\
\text { Time } \\
\text { (Hrs) }\end{array}$ & $\begin{array}{c}\text { Verification }(a) \\
\text { Statistic }\end{array}$ & $>600$ & $\begin{array}{l}\text { Power } \\
>1200\end{array}$ & $\frac{\text { Category }}{>1800}$ & $\frac{(\mathrm{kW})}{>2400}$ & ALL \\
\hline $1-6$ & $\begin{array}{l}\text { PC } \\
\text { SS }\end{array}$ & $\begin{array}{l}0.729 \\
0.557\end{array}$ & $\begin{array}{l}0.757 \\
0.541\end{array}$ & $\begin{array}{l}0.814 \\
0.582\end{array}$ & $\begin{array}{l}0.883 \\
0.676\end{array}$ & $\begin{array}{l}0.796 \\
0.596\end{array}$ \\
\hline $7-12$ & $\begin{array}{l}P C \\
\text { SS }\end{array}$ & $\begin{array}{l}0.625 \\
0.300\end{array}$ & $\begin{array}{l}0.675 \\
0.285\end{array}$ & $\begin{array}{l}0.752 \\
0.245\end{array}$ & $\begin{array}{l}0.853 \\
0.252\end{array}$ & $\begin{array}{l}0.726 \\
0.338\end{array}$ \\
\hline $13-18$ & $\begin{array}{l}\text { PC } \\
\text { SS }\end{array}$ & $\begin{array}{l}0.567 \\
0.159\end{array}$ & $\begin{array}{l}0.642 \\
0.159\end{array}$ & $\begin{array}{l}0.728 \\
0.112\end{array}$ & $\begin{array}{r}0.876 \\
-0.003\end{array}$ & $\begin{array}{l}0.703 \\
0.225\end{array}$ \\
\hline $18-24$ & $\begin{array}{l}\text { PC } \\
\text { SS }\end{array}$ & $\begin{array}{l}0.603 \\
0.236\end{array}$ & $\begin{array}{l}0.648 \\
0.225\end{array}$ & $\begin{array}{l}0.728 \\
0.162\end{array}$ & $\begin{array}{r}0.857 \\
-0.018\end{array}$ & $\begin{array}{l}0.709 \\
0.269\end{array}$ \\
\hline ALL & $\begin{array}{l}\text { PC } \\
\text { SS }\end{array}$ & $\begin{array}{l}0.631 \\
0.311\end{array}$ & $\begin{array}{l}0.680 \\
0.301\end{array}$ & $\begin{array}{l}0.755 \\
0.276\end{array}$ & $\begin{array}{l}0.867 \\
0.275\end{array}$ & $\begin{array}{l}0.733 \\
0.357\end{array}$ \\
\hline
\end{tabular}

(a) $P C=$ probability of being correct

SS = Heidke Skill Score (defined in Section 3) 
TABLE A.6. 90\% Confidence SPT Mode 1 Hourly Average Speed Values for Huron, SD

\begin{tabular}{c}
$\begin{array}{c}\text { MOD-2 Power } \\
\text { Category } \\
(\mathrm{kW})\end{array}$ \\
\hline$>600$ \\
$>1200$ \\
$>1800$ \\
$>2400$
\end{tabular}

$90 \%$ Confidence Wind Speed Threshold (m/s)

9.6

11.2

13.0

(a)

(a) Power output can not be equated to any hourly average speed with $90 \%$ confidence 
TABLE A.7. MOS SPT Wind Power Forecast

Verification for Huron, SD

0600 GMT Forecasts

\begin{tabular}{|c|c|c|c|c|c|c|}
\hline $\begin{array}{l}\text { Projection } \\
\text { Time }\end{array}$ & Verification (a) & & & Categor & $(\mathrm{kW})$ & \\
\hline (Hrs) & Statistic & $>600$ & $\geq 1200$ & $>1800$ & $>2400$ & ALL \\
\hline $1-6$ & $\begin{array}{l}\text { PC } \\
\text { SS }\end{array}$ & $\begin{array}{l}0.800 \\
0.601\end{array}$ & $\begin{array}{l}0.817 \\
0.451\end{array}$ & $\begin{array}{l}0.843 \\
0.208\end{array}$ & --- & $\begin{array}{l}0.818 \\
0.509\end{array}$ \\
\hline $7-12$ & $\begin{array}{l}P C \\
S S\end{array}$ & $\begin{array}{l}0.789 \\
0.620\end{array}$ & $\begin{array}{l}0.816 \\
0.498\end{array}$ & $\begin{array}{l}0.837 \\
0.186\end{array}$ & --- & $\begin{array}{l}0.814 \\
0.525\end{array}$ \\
\hline $13-18$ & $\begin{array}{l}\text { PC } \\
\text { SS }\end{array}$ & $\begin{array}{l}0.721 \\
0.448\end{array}$ & $\begin{array}{l}0.769 \\
0.306\end{array}$ & $\begin{array}{l}0.849 \\
0.291\end{array}$ & -- & $\begin{array}{l}0.780 \\
0.417\end{array}$ \\
\hline $18-24$ & $\begin{array}{l}P C \\
S S\end{array}$ & $\begin{array}{l}0.703 \\
0.204\end{array}$ & $\begin{array}{l}0.805 \\
0.158\end{array}$ & $\begin{array}{r}0.864 \\
-0.011\end{array}$ & --- & $\begin{array}{l}0.791 \\
0.208\end{array}$ \\
\hline ALL & $\begin{array}{l}\text { PC } \\
\text { SS }\end{array}$ & $\begin{array}{l}0.772 \\
0.522\end{array}$ & $\begin{array}{l}0.802 \\
0.449\end{array}$ & $\begin{array}{l}0.842 \\
0.208\end{array}$ & --- & $\begin{array}{l}0.805 \\
0.459\end{array}$ \\
\hline
\end{tabular}

1800 GMT Forecasts

\begin{tabular}{|c|c|c|c|c|c|c|}
\hline $\begin{array}{l}\text { Projection } \\
\text { Time } \\
\text { (Hrs) }\end{array}$ & $\begin{array}{l}\text { Verification }(a) \\
\text { Statistic }\end{array}$ & $>600$ & $\begin{array}{l}\text { Power } \\
>1200\end{array}$ & $\frac{\text { Category }}{>1800}$ & $\frac{(k W)}{>2400}$ & ALL \\
\hline $1-6$ & $\begin{array}{l}\text { PC } \\
\text { SS }\end{array}$ & $\begin{array}{l}0.765 \\
0.588\end{array}$ & $\begin{array}{l}0.784 \\
0.426\end{array}$ & $\begin{array}{l}0.854 \\
0.419\end{array}$ & --- & $\begin{array}{l}0.801 \\
0.537\end{array}$ \\
\hline $7-12$ & $\begin{array}{l}\text { PC } \\
\text { SS }\end{array}$ & $\begin{array}{l}0.746 \\
0.417\end{array}$ & $\begin{array}{l}0.811 \\
0.259\end{array}$ & $\begin{array}{l}0.867 \\
0.148\end{array}$ & --- & $\begin{array}{l}0.808 \\
0.380\end{array}$ \\
\hline $13-18$ & $\begin{array}{l}\text { PC } \\
\text { SS }\end{array}$ & $\begin{array}{l}0.778 \\
0.540\end{array}$ & $\begin{array}{l}0.808 \\
0.427\end{array}$ & $\begin{array}{l}0.860 \\
0.116\end{array}$ & -- & $\begin{array}{l}0.815 \\
0.484\end{array}$ \\
\hline $18-24$ & $\begin{array}{l}\text { PC } \\
\text { SS }\end{array}$ & $\begin{array}{l}0.801 \\
0.626\end{array}$ & $\begin{array}{l}0.826 \\
0.601\end{array}$ & $\begin{array}{l}0.832 \\
0.317\end{array}$ & -- & $\begin{array}{l}0.820 \\
0.571\end{array}$ \\
\hline ALL & $\begin{array}{l}P C \\
S S\end{array}$ & $\begin{array}{l}0.769 \\
0.538\end{array}$ & $\begin{array}{l}0.804 \\
0.424\end{array}$ & $\begin{array}{l}0.856 \\
0.285\end{array}$ & $\begin{array}{l}--- \\
---\end{array}$ & $\begin{array}{l}0.810 \\
0.494\end{array}$ \\
\hline
\end{tabular}

0600 and 1800 GMT Forecasts

\begin{tabular}{|c|c|c|c|c|c|c|}
\hline \multirow{2}{*}{$\begin{array}{l}\text { Projection } \\
\text { Time } \\
\text { (Hrs) } \\
\end{array}$} & Verification (a) & \multicolumn{5}{|c|}{ Power Category $(\mathrm{kW})$} \\
\hline & Statistic & $>600$ & $>1200$ & $\geq 1800$ & $\geq 2400$ & ALL \\
\hline $1-6$ & $\begin{array}{l}P C \\
S S\end{array}$ & $\begin{array}{l}0.781 \\
0.594\end{array}$ & $\begin{array}{l}0.800 \\
0.438\end{array}$ & $\begin{array}{l}0.849 \\
0.317\end{array}$ & --- & $\begin{array}{l}0.810 \\
0.526\end{array}$ \\
\hline $7-12$ & $\begin{array}{l}P C \\
S S\end{array}$ & $\begin{array}{l}0.768 \\
0.516\end{array}$ & $\begin{array}{l}0.814 \\
0.405\end{array}$ & $\begin{array}{l}0.852 \\
0.177\end{array}$ & --- & $\begin{array}{l}0.811 \\
0.463\end{array}$ \\
\hline $13-18$ & $\begin{array}{l}P C \\
S S\end{array}$ & $\begin{array}{l}0.749 \\
0.491\end{array}$ & $\begin{array}{l}0.788 \\
0.368\end{array}$ & $\begin{array}{l}0.855 \\
0.225\end{array}$ & --- & $\begin{array}{l}0.797 \\
0.448\end{array}$ \\
\hline $18-24$ & $\begin{array}{l}P C \\
S S\end{array}$ & $\begin{array}{l}0.756 \\
0.497\end{array}$ & $\begin{array}{l}0.815 \\
0.430\end{array}$ & $\begin{array}{l}0.848 \\
0.231\end{array}$ & --- & $\begin{array}{l}0.806 \\
0.467\end{array}$ \\
\hline ALL & $\begin{array}{l}P C \\
S S\end{array}$ & $\begin{array}{l}0.765 \\
0.529\end{array}$ & $\begin{array}{l}0.808 \\
0.420\end{array}$ & $\begin{array}{l}0.847 \\
0.226\end{array}$ & --- & $\begin{array}{l}0.806 \\
0.479\end{array}$ \\
\hline
\end{tabular}

(a) $P C=$ probability of being correct

SS = Heidke Skill Score (defined in Section 3) 
TABLE A.8. 90\% Confidence SPT Model Hourly Average Speed Values for San Gorgonio, CA

\begin{tabular}{c}
$\begin{array}{c}\text { MOD-2 Power } \\
\text { Category } \\
(\mathrm{kW})\end{array}$ \\
\hline$>600$ \\
$>1200$ \\
$>1800$ \\
$>2400$
\end{tabular}

$$
\begin{aligned}
& 90 \% \text { Confidence } \\
& \text { Wind Speed } \\
& \text { Threshold (m/s) }
\end{aligned}
$$

9.9

11.2

12.4

15.5 
TABLE A.9. Semiobjective SPT Wind Power Forecast Verification for San Gorgonio, CA

0600 GMT Forecasts

\begin{tabular}{|c|c|c|c|c|c|c|}
\hline \multirow{2}{*}{$\begin{array}{l}\text { Projection } \\
\text { Time } \\
\text { (Hrs) } \\
\end{array}$} & \multirow{2}{*}{$\begin{array}{c}\text { Verification } \\
\text { Statistic } \\
\end{array}$} & \multicolumn{5}{|c|}{ Power Category (kW) } \\
\hline & & 7600 & $>1200$ & $>1800$ & $\geq 2400$ & ALL \\
\hline $1-6$ & $\begin{array}{l}\text { PC } \\
\text { SS }\end{array}$ & $\begin{array}{l}0.650 \\
0.4442\end{array}$ & $\begin{array}{l}0.646 \\
0.437\end{array}$ & $\begin{array}{l}0.674 \\
0.495\end{array}$ & $\begin{array}{l}0.721 \\
0.381\end{array}$ & $\begin{array}{l}0.673 \\
0.492\end{array}$ \\
\hline $7-12$ & $\begin{array}{l}\text { PC } \\
\text { SS }\end{array}$ & $\begin{array}{l}0.580 \\
0.277\end{array}$ & $\begin{array}{l}0.636 \\
0.366\end{array}$ & $\begin{array}{l}0.674 \\
0.373\end{array}$ & $\begin{array}{r}0.726 \\
-0.056\end{array}$ & $\begin{array}{l}0.654 \\
0.334\end{array}$ \\
\hline $13-18$ & $\begin{array}{l}\text { PC } \\
\text { SS }\end{array}$ & $\begin{array}{l}0.536 \\
0.189\end{array}$ & $\begin{array}{l}0.588 \\
0.270\end{array}$ & $\begin{array}{l}0.661 \\
0.232\end{array}$ & $\begin{array}{l}0.806 \\
0.301\end{array}$ & $\begin{array}{l}0.648 \\
0.320\end{array}$ \\
\hline $18-24$ & $\begin{array}{l}\text { PC } \\
\text { SS }\end{array}$ & $\begin{array}{l}0.602 \\
0.277\end{array}$ & $\begin{array}{l}0.567 \\
0.248\end{array}$ & $\begin{array}{l}0.548 \\
0.194\end{array}$ & $\begin{array}{l}0.783 \\
0.232\end{array}$ & $\begin{array}{l}0.625 \\
0.376\end{array}$ \\
\hline ALL & $\begin{array}{l}P C \\
S S\end{array}$ & $\begin{array}{l}0.593 \\
0.320\end{array}$ & $\begin{array}{l}0.609 \\
0.352\end{array}$ & $\begin{array}{l}0.639 \\
0.359\end{array}$ & $\begin{array}{l}0.758 \\
0.250\end{array}$ & $\begin{array}{l}0.650 \\
0.401\end{array}$ \\
\hline
\end{tabular}

1800 GMT Forecasts

\begin{tabular}{|c|c|c|c|c|c|c|}
\hline $\begin{array}{l}\text { Projection } \\
\text { Time }\end{array}$ & Verification $(a)$ & & & Catego & $(\mathrm{kW})$ & \\
\hline & Statistic & $>600$ & $>1200$ & $>1800$ & $>2400$ & $\mathrm{ALL}$ \\
\hline $1-6$ & $\begin{array}{l}P C \\
S S\end{array}$ & $\begin{array}{l}0.664 \\
0.478\end{array}$ & $\begin{array}{l}0.695 \\
0.507\end{array}$ & $\begin{array}{l}0.719 \\
0.522\end{array}$ & $\begin{array}{l}0.791 \\
0.435\end{array}$ & $\begin{array}{l}0.717 \\
0.528\end{array}$ \\
\hline $7-12$ & $\begin{array}{l}P C \\
S S\end{array}$ & $\begin{array}{l}0.645 \\
0.421\end{array}$ & $\begin{array}{l}0.606 \\
0.356\end{array}$ & $\begin{array}{l}0.628 \\
0.388\end{array}$ & $\begin{array}{l}0.719 \\
0.327\end{array}$ & $\begin{array}{l}0.650 \\
0.440\end{array}$ \\
\hline $13-18$ & $\begin{array}{l}P C \\
S S\end{array}$ & $\begin{array}{l}0.661 \\
0.456\end{array}$ & $\begin{array}{l}0.624 \\
0.386\end{array}$ & $\begin{array}{l}0.613 \\
0.337\end{array}$ & $\begin{array}{l}0.726 \\
0.362\end{array}$ & $\begin{array}{l}0.656 \\
0.445\end{array}$ \\
\hline $18-24$ & $\begin{array}{l}\mathrm{PC} \\
\mathrm{SS}\end{array}$ & $\begin{array}{l}0.582 \\
0.248\end{array}$ & $\begin{array}{l}0.636 \\
0.328\end{array}$ & $\begin{array}{l}0.620 \\
0.164\end{array}$ & $\begin{array}{l}0.754 \\
0.092\end{array}$ & $\begin{array}{l}0.648 \\
0.274\end{array}$ \\
\hline ALL & $\begin{array}{l}P C \\
S S\end{array}$ & $\begin{array}{l}0.638 \\
0.421\end{array}$ & $\begin{array}{l}0.640 \\
0.411\end{array}$ & $\begin{array}{l}0.645 \\
0.368\end{array}$ & $\begin{array}{l}0.748 \\
0.318\end{array}$ & $\begin{array}{l}0.667 \\
0.437\end{array}$ \\
\hline
\end{tabular}

0600 and 1800 GMT Forecasts

\begin{tabular}{|c|c|c|c|c|c|c|}
\hline \multirow{2}{*}{$\begin{array}{l}\text { Projection } \\
\text { Time } \\
\text { (Hrs) } \\
\end{array}$} & Verification $(a)$ & \multicolumn{5}{|c|}{ Power Category (kW) } \\
\hline & Statistic & $>600$ & $>1200$ & $>1800$ & $>2400$ & $\mathrm{ALL}$ \\
\hline $1-6$ & $\begin{array}{l}\text { PC } \\
\text { SS }\end{array}$ & $\begin{array}{l}0.657 \\
0.465\end{array}$ & $\begin{array}{l}0.667 \\
0.480\end{array}$ & $\begin{array}{l}0.694 \\
0.517\end{array}$ & $\begin{array}{l}0.752 \\
0.402\end{array}$ & $\begin{array}{l}0.692 \\
0.514\end{array}$ \\
\hline $7-12$ & $\begin{array}{l}\text { PC } \\
\text { SS }\end{array}$ & $\begin{array}{l}0.613 \\
0.369\end{array}$ & $\begin{array}{l}0.621 \\
0.380\end{array}$ & $\begin{array}{l}0.653 \\
0.395\end{array}$ & $\begin{array}{l}0.723 \\
0.175\end{array}$ & $\begin{array}{l}0.652 \\
0.402\end{array}$ \\
\hline $13-18$ & $\begin{array}{l}\text { PC } \\
\text { SS }\end{array}$ & $\begin{array}{l}0.597 \\
0.326\end{array}$ & $\begin{array}{l}0.606 \\
0.337\end{array}$ & $\begin{array}{l}0.637 \\
0.317\end{array}$ & $\begin{array}{l}0.767 \\
0.350\end{array}$ & $\begin{array}{l}0.652 \\
0.396\end{array}$ \\
\hline $18-24$ & $\begin{array}{l}P C \\
\text { SS }\end{array}$ & $\begin{array}{l}0.592 \\
0.316\end{array}$ & $\begin{array}{l}0.600 \\
0.327\end{array}$ & $\begin{array}{l}0.582 \\
0.205\end{array}$ & $\begin{array}{l}0.769 \\
0.162\end{array}$ & $\begin{array}{l}0.636 \\
0.354\end{array}$ \\
\hline ALL & $\begin{array}{l}P C \\
S S\end{array}$ & $\begin{array}{l}0.615 \\
0.367\end{array}$ & $\begin{array}{l}0.624 \\
0.380\end{array}$ & $\begin{array}{l}0.642 \\
0.363\end{array}$ & $\begin{array}{l}0.753 \\
0.285\end{array}$ & $\begin{array}{l}0.658 \\
0.418\end{array}$ \\
\hline
\end{tabular}

(a) $\mathrm{PC}=$ probability of being correct SS = Heidke Skill Score (defined in Section 3) 
TABLE A.10. MOS SPT Wind Power Forecast Verification for San Gorgonio, CA

0600 GMT Forecasts.

\begin{tabular}{|c|c|c|c|c|c|c|}
\hline $\begin{array}{l}\text { Projection } \\
\text { Time } \\
\text { (Hrs) } \\
\end{array}$ & $\begin{array}{l}\text { Verification }(a) \\
\text { Statistic } \\
\end{array}$ & $>600$ & $\begin{array}{r}P \text { olv } \\
\geq 12001 \\
\end{array}$ & $\begin{array}{l}\text { Category } \\
>1800 \\
\end{array}$ & $\frac{(\mathrm{kW})}{>2400}$ & $\overline{A L L}$ \\
\hline $1-6$ & $\begin{array}{l}P C \\
S S\end{array}$ & $\begin{array}{l}0.712 \\
0.378\end{array}$ & $\begin{array}{l}0.750 \\
0.321 .\end{array}$ & $\begin{array}{l}0.810 \\
0.197\end{array}$ & $\begin{array}{r}0.885 \\
-0.008\end{array}$ & $\begin{array}{l}0.789 \\
0.359\end{array}$ \\
\hline $7-12$ & $\begin{array}{l}P C \\
S S\end{array}$ & $\begin{array}{l}0.728 \\
0.532\end{array}$ & $\begin{array}{l}0.750 \\
0.463\end{array}$ & $\begin{array}{l}0.765 \\
0.100\end{array}$ & $\begin{array}{l}0.885 \\
0.000\end{array}$ & $\begin{array}{l}0.782 \\
0.470\end{array}$ \\
\hline $13-18$ & $\begin{array}{l}P C \\
S S\end{array}$ & $\begin{array}{l}0.645 \\
0.362\end{array}$ & $\begin{array}{l}0.68 i \\
0.336\end{array}$ & $\begin{array}{l}0.810 \\
0.483\end{array}$ & $\begin{array}{r}0.878 \\
-0.011\end{array}$ & $\begin{array}{l}0.754 \\
0.432\end{array}$ \\
\hline $18-24$ & $\begin{array}{l}\mathrm{PC} \\
\text { SS }\end{array}$ & $\begin{array}{l}0.615 \\
0.092\end{array}$ & $\begin{array}{l}0.720 \\
0.053\end{array}$ & $\begin{array}{r}0.840 \\
-0.036\end{array}$ & $\begin{array}{l}0.900 \\
0.000\end{array}$ & $\begin{array}{l}0.769 \\
0.144\end{array}$ \\
\hline ALL & $\begin{array}{l}P C \\
\text { SS }\end{array}$ & $\begin{array}{l}0.684 \\
0.390\end{array}$ & $\begin{array}{l}0.726 \\
0.350\end{array}$ & $\begin{array}{l}0.801 \\
0.350\end{array}$ & $\begin{array}{r}0.885 \\
-0.007\end{array}$ & $\begin{array}{l}0.774 \\
0.401\end{array}$ \\
\hline
\end{tabular}

1800 GMT Forecasts;

\begin{tabular}{|c|c|c|c|c|c|c|}
\hline $\begin{array}{l}\text { Projection } \\
\text { Time }\end{array}$ & Verification (a) & & & Categor & & \\
\hline & Statistic & $>600$ & $>1200$ & $>1800$ & $>2400$ & ALL \\
\hline $1-6$ & $\begin{array}{l}P C \\
S S\end{array}$ & $\begin{array}{l}0.718 \\
0.543\end{array}$ & $\begin{array}{l}0.703 \\
0.389\end{array}$ & $\begin{array}{l}0.813 \\
0.506\end{array}$ & $\begin{array}{l}0.868 \\
0.000\end{array}$ & $\begin{array}{l}0.776 \\
0.515\end{array}$ \\
\hline $7-12$ & $\begin{array}{l}P C \\
S S\end{array}$ & $\begin{array}{l}0.700 \\
0.387\end{array}$ & $\begin{array}{l}0.756 \\
0.39 \%\end{array}$ & $\begin{array}{l}0.814 \\
0.257\end{array}$ & $\begin{array}{l}0.890 \\
0.000\end{array}$ & $\begin{array}{l}0.790 \\
0.409\end{array}$ \\
\hline $13-18$ & $\begin{array}{l}P C \\
S S\end{array}$ & $\begin{array}{l}0.679 \\
0.357\end{array}$ & $\begin{array}{l}0.726 \\
0.307\end{array}$ & $\begin{array}{r}0.821 \\
-0.038\end{array}$ & $\begin{array}{r}0.884 \\
-0.009\end{array}$ & $\begin{array}{l}0.778 \\
0.349\end{array}$ \\
\hline $18-24$ & $\begin{array}{l}\text { PC } \\
\text { SS }\end{array}$ & $\begin{array}{l}0.679 \\
0.396\end{array}$ & $\begin{array}{l}0.758 \\
0.541\end{array}$ & $\begin{array}{l}0.774 \\
0.365\end{array}$ & $\begin{array}{l}0.868 \\
0.000\end{array}$ & $\begin{array}{l}0.770 \\
0.462\end{array}$ \\
\hline ALL & $\begin{array}{l}\text { PC } \\
\text { SS }\end{array}$ & $\begin{array}{l}0.694 \\
0.429\end{array}$ & $\begin{array}{l}0.731 \\
0.396\end{array}$ & $\begin{array}{l}0.810 \\
0.333\end{array}$ & $\begin{array}{r}0.879 \\
-0.005\end{array}$ & $\begin{array}{l}0.778 \\
0.441\end{array}$ \\
\hline
\end{tabular}

0600 and 1800 GMT Forecasts

\begin{tabular}{|c|c|c|c|c|c|c|}
\hline $\begin{array}{l}\text { Projection } \\
\text { Time }\end{array}$ & Verification (a) & & Pow & Catego & & \\
\hline & Statistic & $\geq 600$ & $>12010$ & $>1800$ & $>2400$ & ALL \\
\hline $1-6$ & $\begin{array}{l}P C \\
S S\end{array}$ & $\begin{array}{l}0.715 \\
0.479\end{array}$ & $\begin{array}{l}0.727 \\
0.367\end{array}$ & $\begin{array}{l}0.812 \\
0.385\end{array}$ & $\begin{array}{r}0.877 \\
-0.007\end{array}$ & $\begin{array}{l}0.783 \\
0.455\end{array}$ \\
\hline $7-12$ & $\begin{array}{l}P C \\
S S\end{array}$ & $\begin{array}{l}0.715 \\
0.474\end{array}$ & $\begin{array}{l}0.753 \\
0.4315\end{array}$ & $\begin{array}{l}0.786 \\
0.160\end{array}$ & $\begin{array}{l}0.887 \\
0.000\end{array}$ & $\begin{array}{l}0.785 \\
0.447\end{array}$ \\
\hline $13-18$ & $\begin{array}{l}P C \\
S S\end{array}$ & $\begin{array}{l}0.662 \\
0.364\end{array}$ & $\begin{array}{l}0.70 .4 \\
0.329\end{array}$ & $\begin{array}{l}0.815 \\
0.339\end{array}$ & $\begin{array}{r}0.881 \\
-0.010\end{array}$ & $\begin{array}{l}0.765 \\
0.402\end{array}$ \\
\hline $18-24$ & $\begin{array}{l}P C \\
S S\end{array}$ & $\begin{array}{l}0.646 \\
0.253\end{array}$ & $\begin{array}{l}0.7313 \\
0.3515\end{array}$ & $\begin{array}{l}0.808 \\
0.281\end{array}$ & $\begin{array}{l}0.885 \\
0.000\end{array}$ & $\begin{array}{l}0.769 \\
0.341\end{array}$ \\
\hline ALL & $\begin{array}{l}\mathrm{PC} \\
\text { SS }\end{array}$ & $\begin{array}{l}0.689 \\
0.409\end{array}$ & $\begin{array}{l}0.727 \\
0.37 ?\end{array}$ & $\begin{array}{l}0.805 \\
0.297\end{array}$ & $\begin{array}{r}0.882 \\
-0.006\end{array}$ & $\begin{array}{l}0.776 \\
0.421\end{array}$ \\
\hline
\end{tabular}

(a) PC = probability of being correct

SS = Heidke Skill Score (defined in Section 3) 


\section{$\underline{\text { DISTRIBUTION }}$}

No. of

Copies

OFFSITE

G. P. Tennyson

Department of Energy

Albuquerque Operations office

P.0. Box 5400

Albuquerque, NM 87110

3 D. Ancona/J. Cadogan/L. V. Divone Department of Energy

Wind Energy Technology Division 1000 Independence Avenue S.W. Forrestal Building, Room $5 \mathrm{H048}$ Washington, DC 20585

27 DOE Technical Information Center

C. I. Aspliden

Battelle Memorial Institute Washington Operations Office 2030 M Street, N.W.

Washington, DC 20036

P. Lissaman/A. Zalay

Aerovironment, Inc.

145 Vista Avenue

Pasadena, CA 91107

L. A. Liljedah 1

Department of Agriculture

Agriculture Wind Energy Program

Building 001, Room 126 BARC-West

Beltsville, MD 20705

R. N. Clark

U.S. Department of Agriculture Southwest Great Plains Research Center

Bushland, TX 79102

D. McGrew

Boeing Engineering \& Construction

P.0. Box 3707, Mail Stop 9A-67

Seattle, WA 98124
No. of

Copies
N. Butler

Bonneville Power Administration

P.0. Box 3621

Portland, OR 97208

W. J. Formica

9920 Forrest Lane \#227

Dallas, TX 75243

C. Notis

Freese-Notis Weather, Inc.

1453 N.E. 66th Avenue

Des Moines, IA 50313

W. Frost

FWG Associates, Inc.

271A Lakewood Drive

Tullahoma, TN 37388

T. D. Younkins

General Electric Systems

Engineering Department

General Electric Company

1 River Road

Schenectady, NY 12345

W. Johnston

Hawaiian Electric Co., Inc.

900 Richards Street

Honolulu, HI 96813

D. W. Trettel

Murray and Trettel, Inc.

Northfield, IL 60093

P. French

NASA Scientific and Technical Information Facility

P.0. Box 8757

Baltimore/Washington International Airport

Baltimore, MD 21240 
E. W. Hewson

Department of Atmospheric Sciences Oregon State University

Corvallis, OR 97331

Tom Hillesland

Pacific Gas \& Electric Co.

Department of Engineering Research 3400 Crow Canyon Road

San Ramon, CA 94583

C. D. Stulz

Pacific Power

920 S.W. 6th Avenue

Portland, OR 97204

R. J. Yinger

Southern California Edison Co.

P.0. Box 800

Rosemead, CA 91770

B. Bailey

Atmospheric Sciences Research Center

State University of New York at Albany

Albany, NY 12222

S. M. Chan

Systems Control, Inc.

1801 Page Mill Road

P.0. Box 10025

Palo Alto, CA 94303

R. H. Kirchhoff

Department of Mechanical

Engineering

University of Massachusetts

Amherst, MA 01003

R. A. Pielke

Department of Environmental Sciences

Clark Hall

University of Virginia

Charlottesville, VA 22903
W. A. Vachon

P.0. Box 149

Manchester, MA 01944

E. L. Davis

U.S. 'Nindpower, Inc.

6421 B. South Front Road

Liverinore, CA 94550

ONSITE

2 DOE Richland Operations Office

H. E. Ransom/D. R. Segna

51 Pacific Northwest Laboratory

W. R. Barchet

J. W. Buck

J. R. Connell

D. W. Dragnich

C. E. Elderkin

D. L. Elliott

R. L. George

P. C. Hays

S. K. Heflick

A. H. Miller

E. L. Owczarski

D. C. Powell

D. S. Renne

H. L. Wegley (10)

L. L. Wendel 1

Technical Information L.ibrary (5)

Putlishing Coordination (2)

WCF'E Program Office (15) 